\title{
ANALYSING FIRM-SPECIFIC AND TYPE-SPECIFIC DETERMINANTS OF ECO-INNOVATION
}

\author{
Pablo DEL RÍO ${ }^{\mathrm{a}}$, Desiderio ROMERO-JORDÁN ${ }^{\mathrm{b}}$, Cristina PEÑASCO ${ }^{\mathrm{a}}$ \\ ${ }^{a}$ Institute for Public Policies and Goods (IPP), Consejo Superior de Investigaciones Científicas, \\ C/Albasanz 26-28, 28037 Madrid, Spain \\ ${ }^{b}$ Universidad Rey Juan Carlos, Paseo de los Artilleros s/n, 28032 Madrid, Spain
}

Received 08 April 2013; accepted 13 April 2014

\begin{abstract}
This paper analyses the main determinants influencing different types of eco-innovations and eco-innovators in Spain. We differentiate between two types of eco-innovations (process vs. product and new-to-the-market (NTM) vs. new-to-the-firm (NTF)) and two different types of ecoinnovators (large vs. small and old vs. new firms). Our findings show that new firms are not more eco-innovative and that smaller firms are certainly less eco-innovative. Although the environmental regulation variable is generally a main driver of eco-innovation, there are specific drivers for some eco-innovator and eco-innovation types. This is the case with internal innovation capabilities, which clearly influence small and new firms to eco-innovate, in contrast to large and old firms. Those capabilities are also a driver of NTM eco-innovation versus NTF eco-innovation. Involvement in external knowledge flows and cooperation is also a crucial variable for small firms to eco-innovate and a main driver of NTM versus NTF eco-innovation. Contrary to expectations, there are a few differential drivers for products vs. process eco-innovations. Energy/material cost reductions and environmental regulation influence both eco-innovation types, whereas the demand-pull from the market is absent for both, probably due to a relatively low degree of environmental consciousness and/or willingness to pay for eco-products by its consumers.
\end{abstract}

Keywords: eco-innovators, determinants, probit model, environmental regulation, internal capabilities.

JEL Classification: O30, Q55.

\section{Introduction}

There is a widespread consensus that eco-innovation plays a key role in sustainability transitions. Eco-innovations are innovations with lower environmental impacts, whether the main motivation for their development or deployment is environmental or not (see Carrillo-Hermosilla et al. 2010). If eco-innovation is so relevant in this context, then a main issue

Corresponding author Pablo del Río

E-mail:pablo.delrio@csic.es 
is which are the main determinants (drivers and barriers) for those firms either developing or adopting them (i.e., "eco-innovators") and whether public policy is necessary in order to activate those determinants or remove the barriers.

The literature on firm-level determinants to eco-innovation is abundant (see 1.1). The empirical studies have shown that, when taking the decision to eco-innovate, firms are influenced by a wide array of internal and external factors to the firm, as well as by the characteristics of those eco-innovations (del Río 2009). However, what is missing in the literature is an analysis of how the relevance of those determinants differs for distinct types of eco-innovators and eco-innovations. It is highly likely that the same determinant does not have the same influence on firms with different characteristics (for example, small vs. large eco-innovators). Likewise, drivers might differ for types of different eco-innovations (for example, for process vs. product eco-innovations). If this is so, and policy-makers want to support one specific type of eco-innovation/eco-innovator, then an analysis of those differential determinants is policy-relevant. While the literature on firm-level determinants is wide, the literature on the determinants for different types of eco-innovators and eco-innovations is not, with the possible exception of process vs. product eco-innovations. This paper tries to close this gap.

Therefore, the aim of this paper is to analyse the main determinants influencing eco-innovators in Spain with respect to general innovators with the help of econometric techniques, considering different types of eco-innovations and eco-innovators. In addition, our paper contributes to the literature in other directions. A relatively recent but abundant literature has analysed the determinants to eco-innovations, although generally not in a Southern European context. Furthermore, the analysis of drivers of eco-innovation compared to general innovation has been neglected in the literature, with some exceptions (see 1.1).

Accordingly, the paper is structured as follows. The next section provides a literature review and puts forward the hypotheses. Section 2 describes the data and methods and discusses the main results. The last section concludes.

\section{Theoretical framework and research hypotheses}

\subsection{Links to the existing literature on the determinants to eco-innovation}

The literature on the drivers to eco-innovation can be classified in two main groups, i.e., the literature on the general determinants to eco-innovation, which is relatively abundant (Table 1), and the very recent literature on the specific determinants to eco-innovation versus those of general innovation, which is not (Table 2). Many drivers to innovation in general (i.e., for normal innovation) are likely to be shared by eco-innovation. Therefore, policies supporting innovation in general would also lead to eco-innovation. However, eco-innovation has distinctive (additional) features, which are mostly related to the double externality problem and the more relevant role of public policies acting as a main driver ${ }^{1}$. Therefore, policy makers willing to specifically promote eco-innovation should take these differential drivers into account.

\footnotetext{
${ }^{1}$ Eco-innovations are generally subject to a double externality (Rennings 2000). In addition to the negative externality of pollution, which leads to an under-provision of eco-innovations, i.e., below the social optimum level, technological change has public good features which discourage their development and deployment. These result from the spillovers in the innovation process, which facilitate imitation, in spite of patent protection (Rennings 2000).
} 


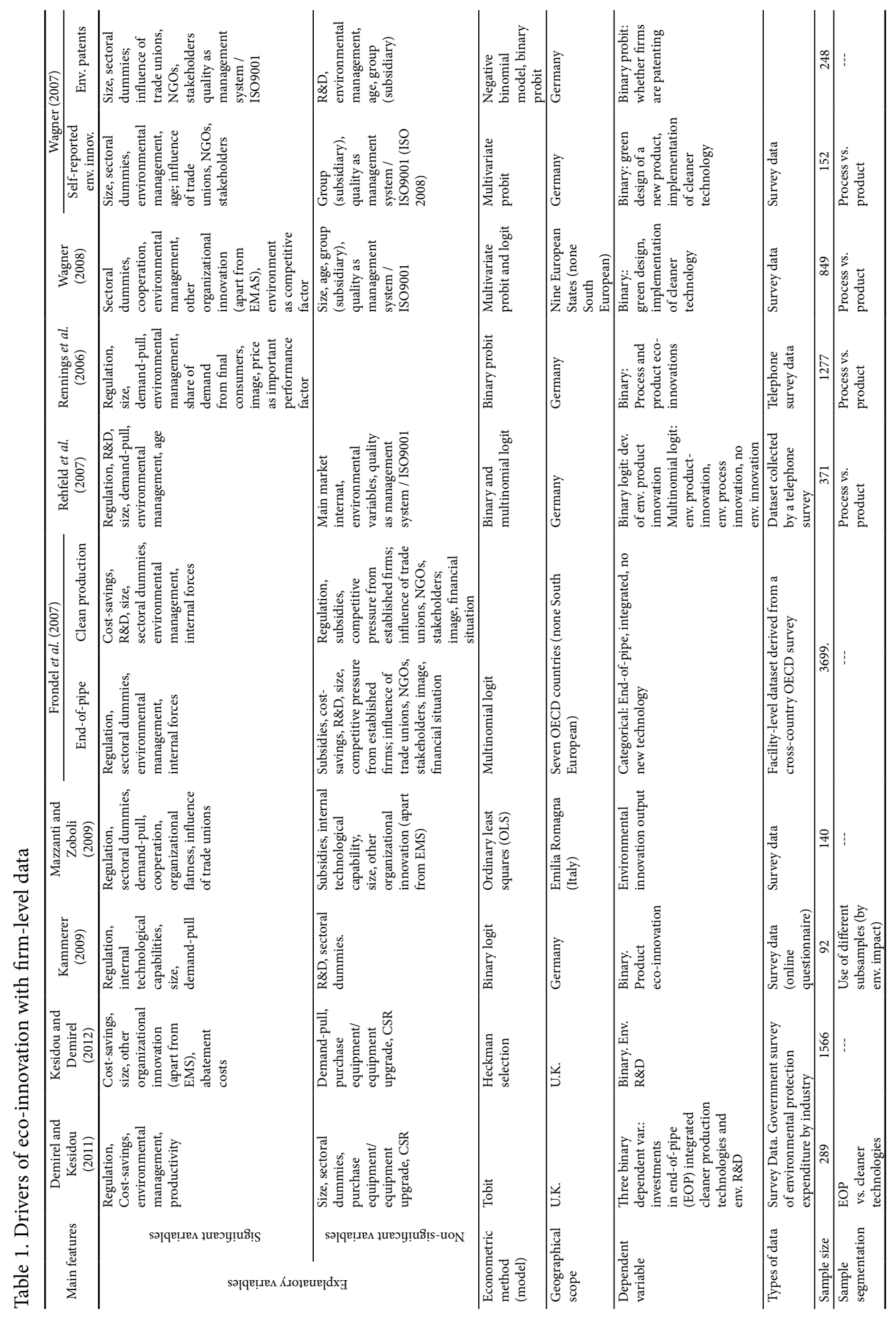


苟

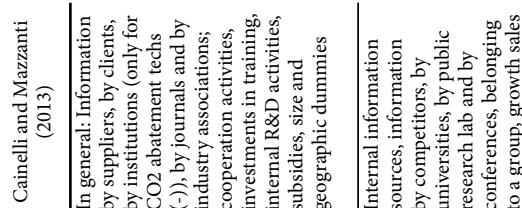

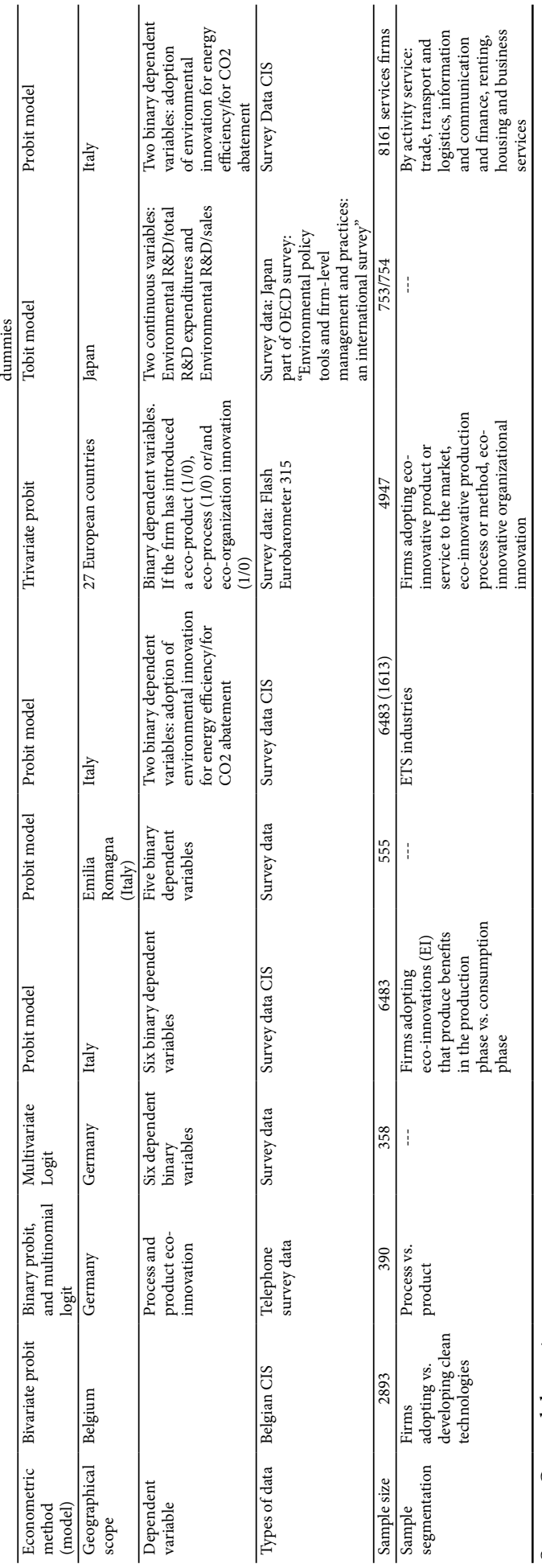

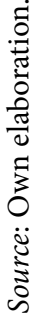




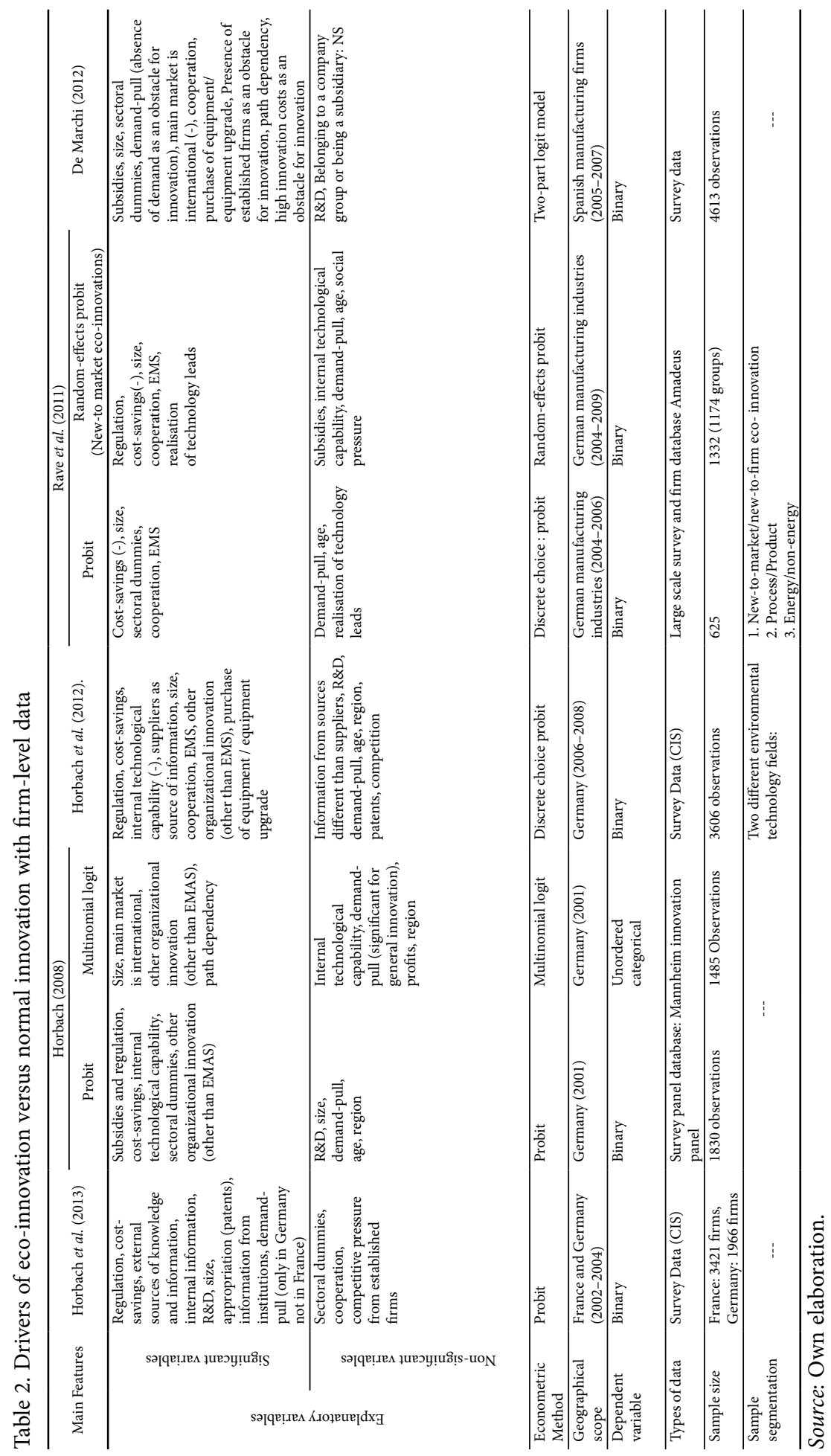


One of the findings of the literature review is that the set of potential explanatory variables for the analysis of the determinants to eco-innovation is large. Indeed, there is no standard method to choose those variables. No single body of literature has succeeded in providing a comprehensive framework for the study of eco-innovation drivers (Diaz-López 2008; Mazzanti, Zoboli 2009). Several theoretical approaches are relevant to guide the selection of explanatory variables, including environmental economics, the systems of innovation perspective and evolutionary economics and the resource-based view (RBV) of the firm. The combination of those approaches suggests that firms are influenced by internal (resources and capabilities) and external factors (e.g., regulation) when taking the decision to eco-innovate (del Río 2009).

Tables 1 and 2 show that, in fact, the list of determinants used in the econometric studies is very large. A few variables are common to most studies. Regulation, size, sectoral dummies and environmental management systems (EMS) are included in at least half of the models. Three particularly relevant variables in those studies which compare drivers to environmental innovation versus normal innovations (Table 2) are cooperation, demand-pull and cost-savings. Other variables have been much less often used. In particular, internal factors to the firm such as resources, capabilities and competences, which are important drivers of innovation performance (see below), have seldom been considered in the empirical literature on eco-innovation, mostly due to the difficulty to include these factors into econometric models, given the unavailability of data.

Public policies play a crucial role in the promotion of eco-innovation and are found to be statistically significant in most studies. They can either be in the form of "sticks" (environmental policies) or "carrots" (i.e., subsidies). The relevance of public policies is related to the aforementioned double externality problem, which is specifically faced by eco-innovation (Rennings 2000; Horbach et al. 2013). Thus, eco-innovations are more policy-driven and possibly less market-driven than other innovations (Horbach 2008; Horbach et al. 2012).

Regarding internal innovation capabilities, in the general innovation theory, firm's technological capabilities are emphasized (see e.g. Baumol 2002; Rosenberg 1974). They comprise the physical and knowledge capital stock of a firm to develop new products and processes. To build up such a capital stock, inputs like R\&D investment or further education of the employees are necessary (Horbach 2008). R\&D expenditures improve the "knowledge capital" of the firms (affecting innovation) and their "absorptive capacity" of external knowledge (influencing adoption) (Cainelli et al. 2012). Horbach et al. (2012) argue that, as a relatively new technology field, eco-innovations are characterized by higher innovation intensity. De Marchi (2012) argues that absorptive capacity is more important in contexts such as those faced by eco-innovations, with high market uncertainties and technological turbulences. The firm is likely to have greater innovation capabilities when part of a larger group because it has access to the parent firm's resources and knowledge (de Marchi 2012). For Horbach et al. (2013), however, the role of R\&D in eco-innovation is not well documented. Finally, the financial situation of the company, its productivity level (Mazzanti, Zoboli 2009) and its growth (Rave et al. 2011) is likely to positively affect eco-innovation.

Regarding cooperation, the general importance of network relationships for innovation activities has been acknowledged only recently in the specific case of eco-innovation (Ca- 
inelli et al. 2012). The literature stresses that eco-innovations are more cooperation-intensive than general innovations (Horbach et al. 2013; Horbach 2008; Cainelli et al. 2012; de Marchi 2012; Rennings, Rammer 2009). Horbach et al. (2013) argue that eco-innovation requires more external sources of knowledge and information than innovation in general because eco-innovations are often characterized by relatively new technologies, where more basic research is needed. For Cainelli et al. (2012), networking and cooperation with universities becomes essential for achieving more radical and relatively new innovations such as eco-innovation. For de Marchi (2012), eco-innovations require more cooperation than other innovations, given their systemic and complex character. Eco-innovators have to leverage on the competences of external partners to a higher extent than other innovators.

The literature on eco-innovation vs. normal innovation barely supports the market-pull for eco-innovation (Horbach et al. 2012). Although customer benefits play a key role in product eco-innovations (Kammerer 2009; Horbach et al. 2012), eco-friendly products are still expensive (Rehfeld et al. 2007; Horbach et al. 2012). In countries with low environmental awareness and/or willingness-to-pay for product eco-innovations, a market-pull cannot be expected. According to the Eurobarometer, Spain ranks well below the EU average regarding willingness-to-pay for eco-products (EC 2011: 157). In a recent analysis of environmental management practices (i.e., including eco-innovations) in Spain and Italy, Ormazábal and Sarregi (2014) show a limited impact of "market requirements".

The evidence on cost savings is also rather ambiguous. Only half of the studies including this variable show a positive and statistically significant impact. Several reasons have been proposed to justify the alleged greater relevance of cost savings in eco-innovation. For Horbach et al. (2013), the capacity of firms to eco-innovate depends on their ability to combine productive efficiency and product quality with environmental objectives. Environmental regulation may make firms recognize the previously untapped cost-saving potentials of eco-innovations (Rave et al. 2011). Notwithstanding, why should cost reductions be a more relevant driver for eco-innovation than for general innovation? In order to be successful, any innovation has to reduce costs or increase the quality of the product, and this is true whether the innovation has an environmental component or not.

Other interesting conclusions about the studies on eco-innovation can be inferred from Tables 1 and 2. First, the literature has strongly relied on German data. A Southern European perspective has been missing, with some exception, including del Río (2005), del Río et al. (2011) and de Marchi (2012) for Spain and Mazzanti and Zoboli (2009) and Cainelli et al. (2012) for Italy. Regarding the method, probit models dominate, followed by logit models. Most importantly, very few papers focus on the role of different eco-innovation and eco-innovator types, as analysed in this paper. Some authors pay attention to the different determinants for process and product eco-innovations (Rennings et al. 2006; Rehfeld et al. 2007). In contrast, the determinants to new-to-the-firm vs. new-to-the-market eco-innovations have seldom been analyzed (Rave et al. 2011 is an exception). No paper assesses the differential determinants to eco-innovation in either large or small firms. Finally, as argued in the next subsection, the role of firm age in the propensity to eco-innovate is a recent and unsettled topic. 
Therefore, the focus of this paper is on the analysis of the role of different eco-innovation and eco-innovator types (size and age of the firm, and new-to-the-market/newto-the-firm and products/process eco-innovations). We focus on crucial determinants of eco-innovation (public policies, internal innovation capabilities and cooperation) and also on those for which the influence is not settled (market-pull and cost-savings), using the rest of factors as control variables. The analysis is performed using the eco-innovation vs. normal innovation modality.

\subsection{Firm-size and type-specific determinants in eco-innovation. Main hypotheses}

\subsubsection{Large vs. small firms}

Size has generally shown to positively affect the eco-innovative behaviour of firms due to several reasons: a higher public visibility for larger firms and the corresponding pressure from environmental NGOs (Kesidou, Demirel 2012; Kammerer 2009), a higher amount of financial and human resources (Kammerer 2009; Walz 2011; Rave et al. 2011), the existence of a systemized R\&D department (Kesidou, Demirel 2012), the difficulties of small and medium size firms (SMEs) in facing the complexity of environmental innovations and the investments needed to switch to greener technologies (De Marchi 2012) and economies of scale (Mazzanti, Zoboli 2009).

\subsubsection{New versus old firms}

Similarly to the discussions in the general innovation literature (see Acemoglu, Cao 2015 for an overview), incremental eco-innovations in traditional industrial sectors might be mainly developed by large established firms or their suppliers (as found by Oltra 2008), whereas disruptive innovation is probably triggered by new entrants who challenge the dominant technological regime (as argued by Bergek et al. 2008). For some authors, the newer the firm, the more likely it is to eco-innovate (Walz 2011; UNECE 2011; OECD 2011). However, the influence of firm age on eco-innovation is undetermined in the empirical literature, with some authors showing a non-significant effect (Horbach 2008; Veugelers 2012; Rave et al. 2011) and others reporting a weak positive effect (Wagner 2007).

The accumulation of organizational resources and knowledge is good for innovation in general and eco-innovation in particular (Rave et al. 2011). Some authors argue that eco-innovation is high, systemic and complex innovation (Andersen 2011; Marchi 2012; Horbach et al. 2013). If this so, then, a greater internal innovation capacity and involvement in external knowledge flows and cooperation is required for eco-innovation compared to general innovation. This is even more important for new firms than for existing ones, since the former have not accumulated internal capabilities over the years and need to build relevant knowledge network relationships.

\subsubsection{New-to-the-market (NTM) vs. new-to-the-firm (NTF) eco-innovations}

Eco-innovations encompass NTM innovations, but also those with a lower degree of novelty, i.e., NTF innovations. The differential determinants of these eco-innovations have not been analysed, with the notable exception of Rave et al. (2011). Since the degree of radical- 
ity, disruption, complexity and systemicness can be expected to be higher for NTM than for NTF eco-innovations, the amount of funds, internal innovation capabilities and degree of cooperation with external actors required to develop or adopt NTM eco-innovations would also be greater. Indeed, Rave et al. (2011) show that NTM eco-innovations typically require more fundamental and often collaborative $\mathrm{R} \& \mathrm{D}$ activities.

If demand-pull factors shape diffusion rather than innovation (Horbach 2008; Horbach et al. 2013), then demand-pull would affect more NTF than NTM eco-innovations. NTM eco-innovations can be expected to be more product-oriented, driven by the opportunity to achieve technical leads and introduce new products or replace existing ones, and NTF tend to be more process-oriented, aimed at having greater production flexibility and capacity and lower costs. Compliance with environmental regulation and cost reductions play a more relevant role in the diffusion of known, more incremental firm-level (i.e., NTF) eco-innovations (Rave et al. 2011; Frondel et al. 2007; del Río 2005; Veugelers 2012).

\subsubsection{Process vs. product eco-innovations}

The literature suggests that process eco-innovations would be primarily undertaken to reduce energy and resource costs and comply with environmental regulation, whereas product eco-innovations would be driven by demand factors, opportunities in environmental markets and social pressure (Rave et al. 2011; Rehfeld et al. 2007; Rennings et al. 2006; Frondel et al. 2007; Veugelers 2012). Integrated environmental protection at the level of the process generally confers little or no additional benefit on the customer and therefore receives comparatively little reward from the market (Cleff, Rennings 1999). On the other hand, Rehfeld et al. (2007) and Horbach et al. (2013) show that product eco-innovations require greater internal innovation capabilities and external knowledge sources.

Therefore, the following hypotheses are proposed (Table 3).

Table 3. Hypotheses proposed in this paper

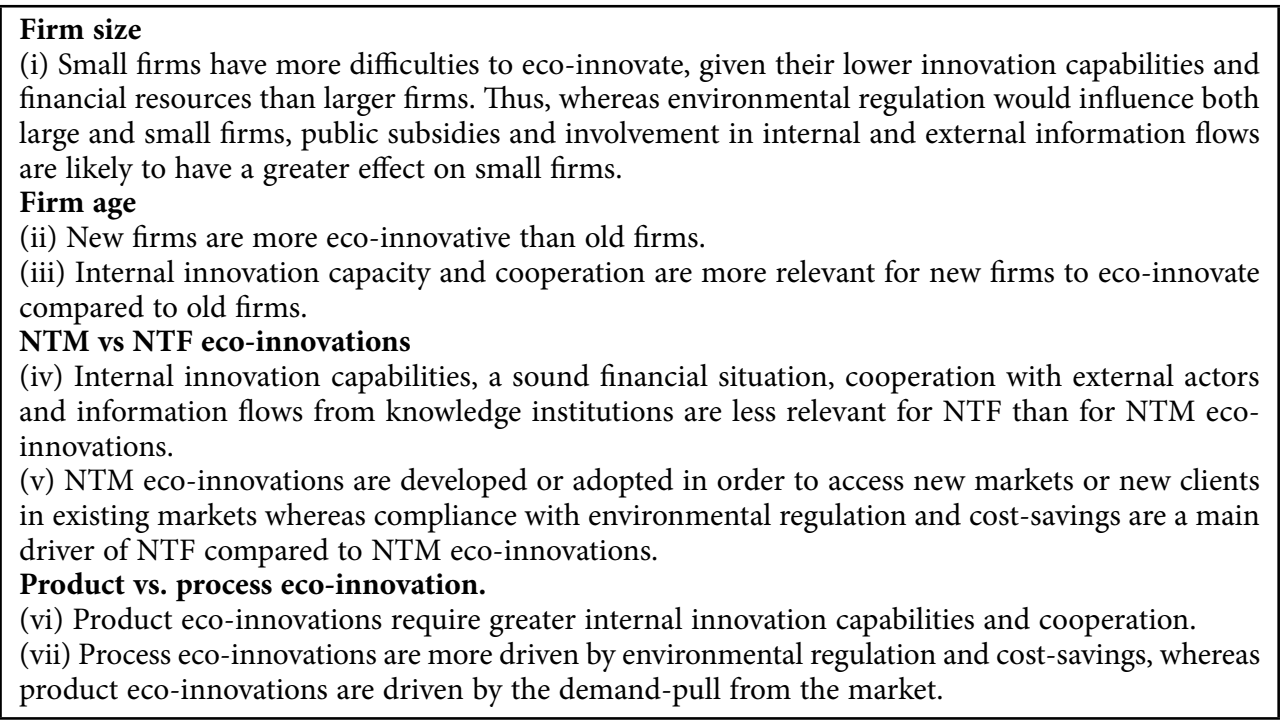




\section{The econometric analysis}

\subsection{The data}

We use annual data from the Spanish Technological Innovation Panel database (PITEC) which, based on the Community Innovation Survey (CIS) methodology, collects information on innovation in Spanish firms ${ }^{2}$. Although PITEC allows us to analyse distinctive features and determinants of eco-innovators versus general innovators, a disadvantage of this database is that it cannot be used as a panel of data (PITEC 2007). This is due to changes in, both, the sample and the questionnaire which prevents, in most cases, comparisons between years (de Marchi 2012). Thus, our study focuses on data provided by the 2009 questionnaire, which covers the period 2007-2009 for some variables. We also include data provided by the 2008 survey in order to use lagged variables as instrumental variables. Therefore, our sample includes manufacturing firms which were present in both the 2008 and 2009 surveys and had no "incidences". A company is considered to have an "incidence" if it has been closed, temporarily closed, merged or absorbed by another firms (actually no longer existing as such), fully split or untraceable. The sample includes 3341 firms which belong to all the industrial sectors (see Table A1 in the Appendix).

For our econometric analysis, the dependent variable is built based on a question introduced by PITEC about how important is reducing environmental impacts as an aim to develop some kind of innovation ${ }^{3}$. A firm is an eco-innovator if it had introduced a process or product innovation with a high positive environmental impact between 2007 and 2009. About $28 \%$ of firms in our sample are "highly eco-innovating firms" (948 firms). This is a similar approach to Horbach (2008). The explanatory variables are described in detail in Table A2 in the appendix. Table A3 shows simple correlations between the explanatory variables.

Firms are considered "old" if they were set up before 1990 and "new" otherwise. They are "smaller" if they have less than 100 employees, and "larger" otherwise.

The external drivers of eco-innovation include two policy variables, environmental regulations and public subsidies. Internal determinants include R\&D expenditures, firm age, external knowledge acquisition expenditures, firm size, whether it has foreign equity or not, its export capacity, changes in turnover between 2008 and 2009, turnover per employee in 2009, whether the firm has been a patent applicant in 2007-2009 and whether it belongs to a high-technology sector. In addition, we include the importance attached to several factors when firms innovate (increasing the range of products, replacing old products or process, increasing market share, increasing the quality of products, improving production processes, reducing costs), the perceived barriers to innovation (lack of internal or/and

\footnotetext{
2 The 2008 wave of the CIS survey includes an optional one-page set of questions on eco-innovation. Unfortunately, Spain is not one of the countries that included the environmental module.

${ }^{3}$ In PITEC this question is answered with a four-value categorical variable, where the values 1, 2, 3 and 4 stand for "high", "medium", "low" and "non-applicable" importance attached to the reduction of environmental impacts, respectively. We have transformed this categorical variable into a binary variable in which the value of 1 is for companies which attach a high importance to the reduction of environmental impacts and 0 otherwise. This transformation has been made in order to avoid intermediate responses. With intermediate responses (i.e., number 2 above), the importance of the aim of reducing environmental impacts may not be clearly specified (Azofra 1999). This approach is slightly different with respect to other papers using PITEC (see, i.e, De Marchi 2012).
} 
external funds, high innovation costs, lack of qualified staff, lack of information about the new technology, lack of information about new markets, difficulty to find innovation partnerships, existence of a market dominated by established firms, uncertainty on the demand for innovative products, prior innovation in the firm and lack of demand for innovative products) and the importance of different information sources for innovation (knowledge institutions, internal information sources from the company and market players).

\subsection{Method}

Microeconometric methods (logit, probit and tobit models) are useful tools to analyse the probability that firms eco-innovate and the relative influence of each explanatory variable in this decision. We estimate a dichotomous probit model with endogenous regressors in order to take into account the endogeneity problems. The latent variable is defined as the propensity of a company to develop or adopt eco-innovations. When the latent variable $y_{1 i}^{*}$ exceeds a given threshold, the HEI variable takes the value of 1, 0 otherwise. Therefore, the dichotomous model was specified as (1):

$$
\begin{aligned}
& y^{*}=x_{i}^{\prime} \beta+\varepsilon_{i}, \quad \varepsilon_{i} \sim N[0,1], \\
& y_{i}=1 \text { if } y^{*}{ }_{i}>0, \quad y_{i}=0, \text { otherwise. }
\end{aligned}
$$

The estimation of such a probit model should take into account the existence of endogeneity problems that may occur if the regressors are correlated with the error term. This is why we estimate a dichotomous probit model with endogenous regressors $\mathrm{y}_{2 i}$. Formally (2):

$$
y^{*}=y_{2 i} \beta+x_{1 i} \gamma+u_{i} .
$$

$y^{\star}{ }_{1 i}$ is a non-observable latent variable representing the probability that an individual (in this case a firm) develops an eco-innovation. Therefore, the following expression results:

$$
y_{1 i}=\left\{\begin{array}{cc}
0 & y_{1 i}^{*} \leq 0 \\
1 & y_{1 i}^{*}>0
\end{array}\right\},
$$

where $y_{1 i}$ corresponds to the dependent variable of the model.

The $\beta$ parameters are interpreted as marginal effects of the impact of changes in the respective explanatory variable on the probability to eco-innovate (Greene 2008: 772). Subsidies (PUBLICAID) and R\&D expenditures (INTERD) are used as instrumental variables in order to correct for the endogeneity of public financing, a common problem in studies of innovation at the firm level (Almus, Czarnitzki (2003), among others).

\subsection{Main results}

Table 4 provides the results of the estimations for different types of eco-innovators and eco-innovations. Only the main final estimations are reported ${ }^{4}$. They are robust to different types of specifications, i.e., only minor changes in either the sign, magnitude or statistical significance of the estimations occur when we remove one variable from the estimations.

4 Table A4 in the appendix includes the coefficients of the probit model with endogenous regressors. 
Table 4. Results of the estimations (average marginal effects of the probit model with endogenous regressors)

\begin{tabular}{|c|c|c|c|c|c|c|c|c|}
\hline & \multicolumn{2}{|c|}{ Size } & \multicolumn{2}{|c|}{ Age } & \multicolumn{2}{|c|}{ Process/product } & \multicolumn{2}{|c|}{ NTF/NTM } \\
\hline & $\begin{array}{c}\text { small } \\
<100\end{array}$ & $\begin{array}{c}\text { big } \\
\geq 100\end{array}$ & $\begin{array}{c}\text { old } \\
<1990\end{array}$ & $\begin{array}{c}\text { new } \\
\geq 1990\end{array}$ & process & product & NTF & NTM \\
\hline Publicaid & $\begin{array}{c}0.0634^{\star *} \\
(0.031)\end{array}$ & $\begin{array}{c}-0.0128 \\
(0.042)\end{array}$ & $\begin{array}{l}0.0539^{*} \\
(0.028)\end{array}$ & $\begin{array}{c}-0.0105 \\
(0.047)\end{array}$ & $\begin{array}{l}0.0677 \\
(0.058)\end{array}$ & $\begin{array}{l}0.0035 \\
(0.048)\end{array}$ & $\begin{array}{l}0.0473 \\
(0.043)\end{array}$ & $\begin{array}{l}0.0376 \\
(0.056)\end{array}$ \\
\hline Interd & $\begin{array}{l}0.0006 \\
(0.000) \\
\end{array}$ & $\begin{array}{l}0.0006 \\
(0.000) \\
\end{array}$ & $\begin{array}{l}0.0003 \\
(0.000) \\
\end{array}$ & $\begin{array}{c}0.0012^{* *} \\
(0.001) \\
\end{array}$ & $\begin{array}{c}0.0019^{* * *} \\
(0.001)\end{array}$ & $\begin{array}{c}0.0018^{\star *} \\
(0.001) \\
\end{array}$ & $\begin{array}{l}-0.0001 \\
(0.000) \\
\end{array}$ & $\begin{array}{l}0.0015^{*} \\
(0.001) \\
\end{array}$ \\
\hline Extknow & $\begin{array}{c}-0.0014 \\
(0.002)\end{array}$ & $\begin{array}{l}0.0016 \\
(0.002)\end{array}$ & $\begin{array}{l}0.0005 \\
(0.001)\end{array}$ & $\begin{array}{l}0.0017 \\
(0.002)\end{array}$ & Omitted & $\begin{array}{c}0.0034^{* *} \\
(0.001)\end{array}$ & $\begin{array}{l}0.0007 \\
(0.001)\end{array}$ & $\begin{array}{l}0.0020 \\
(0.002)\end{array}$ \\
\hline International & $\begin{array}{c}-0.0368 \\
(0.023)\end{array}$ & $\begin{array}{l}0.0426 \\
(0.039)\end{array}$ & $\begin{array}{c}-0.0166 \\
(0.027)\end{array}$ & $\begin{array}{c}-0.0631^{\star *} \\
(0.030)\end{array}$ & $\begin{array}{c}-0.0071 \\
(0.047)\end{array}$ & $\begin{array}{c}-0.0499 \\
(0.041)\end{array}$ & $\begin{array}{c}-0.0435 \\
(0.030)\end{array}$ & $\begin{array}{c}-0.0415 \\
(0.049)\end{array}$ \\
\hline Techopport & $\begin{array}{c}-0.0376^{* *} \\
(0.016)\end{array}$ & $\begin{array}{c}-0.0131 \\
(0.021) \\
\end{array}$ & $\begin{array}{c}-0.0163 \\
(0.015) \\
\end{array}$ & $\begin{array}{c}-0.0491^{\star *} \\
(0.022) \\
\end{array}$ & $\begin{array}{c}-0.0542^{*} \\
(0.032) \\
\end{array}$ & $\begin{array}{c}-0.04744^{*} \\
(0.028) \\
\end{array}$ & $\begin{array}{c}-0.0339^{*} \\
(0.020)\end{array}$ & $\begin{array}{c}-0.0142 \\
(0.30) \\
\end{array}$ \\
\hline Age & $\begin{array}{l}0.0003 \\
(0.000)\end{array}$ & $\begin{array}{c}-0.0000 \\
(0.000)\end{array}$ & $\begin{array}{l}0.0004 \\
(0.000)\end{array}$ & $\begin{array}{l}0.0014 \\
(0.003)\end{array}$ & $\begin{array}{l}0.0005 \\
(0.001)\end{array}$ & $\begin{array}{c}-0.0000 \\
(0.001)\end{array}$ & $\begin{array}{c}-0.0002 \\
(0.000)\end{array}$ & $\begin{array}{l}0.0000 \\
(0.001)\end{array}$ \\
\hline Pat & $\begin{array}{c}-0.0374^{*} \\
(0.022)\end{array}$ & $\begin{array}{c}-0.0020 \\
(0.026)\end{array}$ & $\begin{array}{c}-0.0340^{*} \\
(0.020)\end{array}$ & $\begin{array}{c}-0.0113 \\
(0.028)\end{array}$ & $\begin{array}{c}-0.0635 \\
(0.069)\end{array}$ & $\begin{array}{c}-0.0305 \\
(0.034)\end{array}$ & $\begin{array}{l}0.0247 \\
(0.030)\end{array}$ & $\begin{array}{c}-0.0394 \\
(0.033)\end{array}$ \\
\hline Roemployee & $\begin{array}{l}0.0045 \\
(0.005) \\
\end{array}$ & $\begin{array}{c}0.0453^{* * *} \\
(0.014) \\
\end{array}$ & $\begin{array}{c}0.0191^{\star \star} \\
(0.009) \\
\end{array}$ & $\begin{array}{l}0.0055 \\
(0.007) \\
\end{array}$ & $\begin{array}{l}0.0025 \\
(0.006) \\
\end{array}$ & $\begin{array}{c}-0.0432 \\
(0.037) \\
\end{array}$ & $\begin{array}{l}0.0074 \\
(0.010) \\
\end{array}$ & $\begin{array}{c}0.0500^{\star *} \\
(0.021)\end{array}$ \\
\hline Owner & $\begin{array}{c}0.0617^{\star *} \\
(0.026)\end{array}$ & $\begin{array}{l}0.0219 \\
(0.022)\end{array}$ & $\begin{array}{l}0.0348^{*} \\
(0.018)\end{array}$ & $\begin{array}{c}0.0697^{\star *} \\
(0.028)\end{array}$ & $\begin{array}{l}0.0461 \\
(0.041)\end{array}$ & $\begin{array}{c}0.0953^{\star * *} \\
(0.034)\end{array}$ & $\begin{array}{l}0.0048 \\
(0.025)\end{array}$ & $\begin{array}{l}0.0566 \\
(0.037)\end{array}$ \\
\hline Turnvar & $\begin{array}{l}0.0001 \\
(0.000) \\
\end{array}$ & $\begin{array}{c}-0.0003 \\
(0.000) \\
\end{array}$ & $\begin{array}{c}-0.0002 \\
(0.000) \\
\end{array}$ & $\begin{array}{l}0.0000 \\
(0.000) \\
\end{array}$ & $\begin{array}{l}0.0001 \\
(0.001) \\
\end{array}$ & $\begin{array}{l}0.0001 \\
(0.000) \\
\end{array}$ & $\begin{array}{l}0.0004 \\
(0.000) \\
\end{array}$ & $\begin{array}{l}0.0000 \\
(0.000) \\
\end{array}$ \\
\hline Widerange & $\begin{array}{c}-0.0082 \\
(0.017) \\
\end{array}$ & $\begin{array}{c}0.020 \\
(0.023) \\
\end{array}$ & $\begin{array}{l}0.0107 \\
(0.016) \\
\end{array}$ & $\begin{array}{c}-0.0222 \\
(0.024) \\
\end{array}$ & $\begin{array}{l}0.0062 \\
(0.039) \\
\end{array}$ & $\begin{array}{c}-0.0033 \\
(0.029) \\
\end{array}$ & $\begin{array}{c}-0.0309 \\
(0.021) \\
\end{array}$ & $\begin{array}{c}0.0699^{* *} \\
(0.033)\end{array}$ \\
\hline Replace & $\begin{array}{l}0.0286^{\star} \\
(0.017)\end{array}$ & $\begin{array}{c}0.0576^{* * *} \\
(0.022)\end{array}$ & $\begin{array}{l}0.0279^{*} \\
(0.017)\end{array}$ & $\begin{array}{c}0.0704^{\star * *} \\
(0.023)\end{array}$ & $\begin{array}{l}0.0388 \\
(0.040) \\
\end{array}$ & $\begin{array}{l}0.0058 \\
(0.027) \\
\end{array}$ & $\begin{array}{l}0.0340 \\
(0.022) \\
\end{array}$ & $\begin{array}{l}0.0538^{\star} \\
(0.031)\end{array}$ \\
\hline Market & $\begin{array}{l}0.0266 \\
(0.018) \\
\end{array}$ & $\begin{array}{c}-0.0193 \\
(0.023) \\
\end{array}$ & $\begin{array}{l}0.0143 \\
(0.017) \\
\end{array}$ & $\begin{array}{l}0.0116 \\
(0.027) \\
\end{array}$ & $\begin{array}{c}-0.0033 \\
(0.040) \\
\end{array}$ & $\begin{array}{l}0.0005 \\
(0.033) \\
\end{array}$ & $\begin{array}{l}0.0179 \\
(0.023)\end{array}$ & $\begin{array}{l}0.0178 \\
(0.035)\end{array}$ \\
\hline Pquality & $\begin{array}{l}0.0126 \\
(0.017) \\
\end{array}$ & $\begin{array}{c}0.0476^{\star *} \\
(0.023)\end{array}$ & $\begin{array}{l}0.0245 \\
(0.017) \\
\end{array}$ & $\begin{array}{l}0.0297 \\
(0.025) \\
\end{array}$ & $\begin{array}{c}-0.0140 \\
(0.039) \\
\end{array}$ & $\begin{array}{l}0.0190 \\
(0.030) \\
\end{array}$ & $\begin{array}{l}0.0039 \\
(0.022) \\
\end{array}$ & $\begin{array}{l}0.0324 \\
(0.033) \\
\end{array}$ \\
\hline Processes & $\begin{array}{l}0.0298^{\star} \\
(0.017)\end{array}$ & $\begin{array}{c}0.0482^{\star \star} \\
(0.024)\end{array}$ & $\begin{array}{c}0.0486^{\star * *} \\
(0.017)\end{array}$ & $\begin{array}{l}0.0048 \\
(0.025) \\
\end{array}$ & $\begin{array}{c}-0.0463 \\
(0.036) \\
\end{array}$ & $\begin{array}{l}0.0388 \\
(0.033) \\
\end{array}$ & $\begin{array}{c}0.0569^{* *} \\
(0.022)\end{array}$ & $\begin{array}{l}0.0483 \\
(0.033) \\
\end{array}$ \\
\hline Regulation & $\begin{array}{c}0.3197^{\star * *} \\
(0.011)\end{array}$ & $\begin{array}{c}0.3414^{* * *} \\
(0.014)\end{array}$ & $\begin{array}{c}0.3340^{* * *} \\
(0.010)\end{array}$ & $\begin{array}{c}0.3172^{\star * *} \\
(0.018)\end{array}$ & $\begin{array}{c}0.3352^{\star * *} \\
(0.025)\end{array}$ & $\begin{array}{c}0.2825^{\star * *} \\
(0.019)\end{array}$ & $\begin{array}{c}0.3431^{* * *} \\
(0.013)\end{array}$ & $\begin{array}{c}0.3378^{\star * *} \\
(0.021)\end{array}$ \\
\hline Savings & $\begin{array}{c}0.0831^{\star * *} \\
(0.017)\end{array}$ & $\begin{array}{c}0.1307^{* * *} \\
(0.022) \\
\end{array}$ & $\begin{array}{c}0.0876^{\star * \star} \\
(0.017) \\
\end{array}$ & $\begin{array}{c}0.01287^{* * *} \\
(0.023) \\
\end{array}$ & $\begin{array}{c}0.1807^{\star * *} \\
(0.033) \\
\end{array}$ & $\begin{array}{c}0.1124^{\star * *} \\
(0.033) \\
\end{array}$ & $\begin{array}{c}0.0768^{* * *} \\
(0.022)\end{array}$ & $\begin{array}{l}0.0556^{\star} \\
(0.033) \\
\end{array}$ \\
\hline Size & $\begin{array}{c}-0.0004 \\
(0.000)\end{array}$ & $\begin{array}{c}0.0001^{* * *} \\
(0.000)\end{array}$ & $\begin{array}{c}0.0001^{\star * *} \\
(0.000)\end{array}$ & $\begin{array}{l}0.0000 \\
(0.000)\end{array}$ & $\begin{array}{c}0.0001^{\star *} \\
(0.000)\end{array}$ & $\begin{array}{l}0.0000 \\
(0.000) \\
\end{array}$ & $\begin{array}{l}0.0000 \\
(0.000) \\
\end{array}$ & $\begin{array}{l}0.0000 \\
(0.000) \\
\end{array}$ \\
\hline & & & & ooperation & & & & \\
\hline 2 & $\begin{array}{l}0.0145 \\
(0.025) \\
\end{array}$ & $\begin{array}{l}0.0430 \\
(0.033) \\
\end{array}$ & $\begin{array}{l}0.0017 \\
(0.024) \\
\end{array}$ & $\begin{array}{c}0.0897^{\star * *} \\
(0.033)\end{array}$ & $\begin{array}{c}0.1228^{\star \star} \\
(0.052)\end{array}$ & $\begin{array}{l}0.0849^{*} \\
(0.049)\end{array}$ & $\begin{array}{l}0.0430 \\
(0.031) \\
\end{array}$ & $\begin{array}{l}0.0014 \\
(0.046) \\
\end{array}$ \\
\hline 3 & $\begin{array}{l}0.0007 \\
(0.020)\end{array}$ & $\begin{array}{l}0.0194 \\
(0.026)\end{array}$ & $\begin{array}{l}0.0029 \\
(0.019)\end{array}$ & $\begin{array}{l}0.0423 \\
(0.031)\end{array}$ & $\begin{array}{l}0.0255 \\
(0.040)\end{array}$ & $\begin{array}{l}0.0504 \\
(0.035)\end{array}$ & $\begin{array}{l}0.0210 \\
(0.027)\end{array}$ & $\begin{array}{c}-0.0128 \\
(0.038)\end{array}$ \\
\hline Nofun & $\begin{array}{l}0.0144 \\
(0.017)\end{array}$ & $\begin{array}{l}0.0415^{*} \\
(0.023) \\
\end{array}$ & $\begin{array}{l}0.0122 \\
(0.017) \\
\end{array}$ & $\begin{array}{c}0.0414^{*} \\
(0.024)\end{array}$ & $\begin{array}{c}-0.0391 \\
(0.037) \\
\end{array}$ & $\begin{array}{l}0.0342 \\
(0.030) \\
\end{array}$ & $\begin{array}{c}0.0476^{\star *} \\
(0.023)\end{array}$ & $\begin{array}{l}0.0195 \\
(0.034) \\
\end{array}$ \\
\hline
\end{tabular}


End of Table 4

\begin{tabular}{|c|c|c|c|c|c|c|c|c|}
\hline & \multicolumn{2}{|c|}{ Size } & \multicolumn{2}{|c|}{ Age } & \multicolumn{2}{|c|}{ Process/product } & \multicolumn{2}{|c|}{ NTF/NTM } \\
\hline & $\begin{array}{c}\text { small } \\
<100\end{array}$ & $\begin{array}{c}\text { big } \\
\geq 100\end{array}$ & $\begin{array}{c}\text { old } \\
<1990\end{array}$ & $\begin{array}{c}\text { new } \\
\geq 1990\end{array}$ & process & product & NTF & NTM \\
\hline Highivcost & $\begin{array}{c}-0.0238 \\
(0.018)\end{array}$ & $\begin{array}{l}0.0010 \\
(0.025)\end{array}$ & $\begin{array}{c}-0.0219 \\
(0.018)\end{array}$ & $\begin{array}{c}0.054 \\
(0.025)\end{array}$ & $\begin{array}{l}0.0372 \\
(0.041)\end{array}$ & $\begin{array}{l}0.0202 \\
(0.032)\end{array}$ & $\begin{array}{c}-0.0128 \\
(0.024)\end{array}$ & $\begin{array}{l}0.0199 \\
(0.034)\end{array}$ \\
\hline Nostaff & $\begin{array}{c}-0.0593^{\star *} \\
(0.026)\end{array}$ & $\begin{array}{c}-0.0120 \\
(0.043)\end{array}$ & $\begin{array}{c}-0.0454 \\
(0.029)\end{array}$ & $\begin{array}{c}-0.0461 \\
(0.037)\end{array}$ & $\begin{array}{c}-0.0014 \\
(0.063)\end{array}$ & $\begin{array}{c}-0.0633 \\
(0.043)\end{array}$ & $\begin{array}{c}-0.0640^{*} \\
(0.037)\end{array}$ & $\begin{array}{c}-0.0100 \\
(0.064)\end{array}$ \\
\hline Notecinfo & $\begin{array}{l}0.0444 \\
(0.031)\end{array}$ & $\begin{array}{c}0.0351 \\
(0.047)\end{array}$ & $\begin{array}{l}0.0477 \\
(0.033)\end{array}$ & $\begin{array}{l}0.0543 \\
(0.043) \\
\end{array}$ & $\begin{array}{l}0.0583 \\
(0.078) \\
\end{array}$ & $\begin{array}{c}0.1296^{\star * *} \\
(0.048)\end{array}$ & $\begin{array}{c}0.0938^{\star *} \\
(0.040)\end{array}$ & $\begin{array}{l}0.0535 \\
(0.074)\end{array}$ \\
\hline Nomarketinfo & $\begin{array}{c}-0.0229 \\
(0.027)\end{array}$ & $\begin{array}{l}-0.034 \\
(0.050)\end{array}$ & $\begin{array}{c}-0.0549^{*} \\
(0.030)\end{array}$ & $\begin{array}{l}0.0004 \\
(0.038)\end{array}$ & $\begin{array}{c}-0.0409 \\
(0.062)\end{array}$ & $\begin{array}{c}-0.0207 \\
(0.047)\end{array}$ & $\begin{array}{c}-0.0526 \\
(0.037)\end{array}$ & $\begin{array}{c}-0.0758 \\
(0.058)\end{array}$ \\
\hline Nopartner & $\begin{array}{c}-0.0532^{\star *} \\
(0.026)\end{array}$ & $\begin{array}{c}-0.0011 \\
(0.040)\end{array}$ & $\begin{array}{c}-0.0382 \\
(0.027)\end{array}$ & $\begin{array}{c}-0.0576 \\
(0.038)\end{array}$ & $\begin{array}{c}-0.1725^{\star * *} \\
(0.066)\end{array}$ & $\begin{array}{l}0.0002 \\
(0.044)\end{array}$ & $\begin{array}{c}-0.0255 \\
(0.034)\end{array}$ & $\begin{array}{c}-0.0271 \\
(0.055)\end{array}$ \\
\hline Estfirms & $\begin{array}{c}0.0357^{\star} \\
(0.019)\end{array}$ & $\begin{array}{c}-0.0062 \\
(0.028)\end{array}$ & $\begin{array}{l}0.0208 \\
(0.020)\end{array}$ & $\begin{array}{l}0.0262 \\
(0.028)\end{array}$ & $\begin{array}{c}0.0923^{* *} \\
(0.042)\end{array}$ & $\begin{array}{c}-0.0214 \\
(0.033)\end{array}$ & $\begin{array}{c}-0.0230 \\
(0.025) \\
\end{array}$ & $\begin{array}{l}0.0544 \\
(0.039)\end{array}$ \\
\hline Uncertd & $\begin{array}{l}-0.004 \\
(0.018)\end{array}$ & $\begin{array}{l}-0.033 \\
(0.026)\end{array}$ & $\begin{array}{c}-0.0036 \\
(0.018)\end{array}$ & $\begin{array}{l}-0.013 \\
(0.026)\end{array}$ & $\begin{array}{c}-0.0720^{*} \\
(0.042)\end{array}$ & $\begin{array}{l}0.0105 \\
(0.031)\end{array}$ & $\begin{array}{c}-0.0013 \\
(0.022)\end{array}$ & $\begin{array}{l}0.0109 \\
(0.036)\end{array}$ \\
\hline Pastiv & $\begin{array}{l}0.0242 \\
(0.053)\end{array}$ & $\begin{array}{l}-0.074 \\
(0.083)\end{array}$ & $\begin{array}{c}-0.0463 \\
(0.063)\end{array}$ & $\begin{array}{l}0.0622 \\
(0.073)\end{array}$ & $\begin{array}{c}-0.0290 \\
(0.095)\end{array}$ & Omitted & $\begin{array}{c}-0.0125 \\
(0.072)\end{array}$ & $\begin{array}{l}0.1193 \\
(0.083)\end{array}$ \\
\hline Nodemand & $\begin{array}{l}0.0159 \\
(0.051) \\
\end{array}$ & $\begin{array}{c}-0.1163 \\
(0.097) \\
\end{array}$ & $\begin{array}{l}0.0380 \\
(0.058) \\
\end{array}$ & $\begin{array}{c}-0.1724^{*} \\
(0.099) \\
\end{array}$ & $\begin{array}{l}0.1049 \\
(0.064) \\
\end{array}$ & $\begin{array}{c}-0.0171 \\
(0.085) \\
\end{array}$ & $\begin{array}{c}-0.0693 \\
(0.069) \\
\end{array}$ & Omitted \\
\hline Interinfo & $\begin{array}{c}0.0349^{\star *} \\
(0.017)\end{array}$ & $\begin{array}{c}0.0016 \\
(0.023)\end{array}$ & $\begin{array}{c}0.0414^{\star *} \\
(0.016)\end{array}$ & $\begin{array}{c}-0.0268 \\
(0.024)\end{array}$ & $\begin{array}{l}0.0608^{*} \\
(0.037)\end{array}$ & $\begin{array}{l}0.0283 \\
(0.028)\end{array}$ & $\begin{array}{c}-0.0031 \\
(0.021)\end{array}$ & $\begin{array}{c}-0.0211 \\
(0.032)\end{array}$ \\
\hline Instinfo & $\begin{array}{c}0.054^{\star * \star} \\
(0.019)\end{array}$ & $\begin{array}{l}0.0223 \\
(0.024)\end{array}$ & $\begin{array}{c}0.0492^{* * *} \\
(0.018)\end{array}$ & $\begin{array}{l}0.0264 \\
(0.027)\end{array}$ & $\begin{array}{c}-0.0389 \\
(0.044)\end{array}$ & $\begin{array}{l}0.0567^{\star} \\
(0.033)\end{array}$ & $\begin{array}{l}0.0207 \\
(0.024)\end{array}$ & $\begin{array}{l}0.0536^{*} \\
(0.034)\end{array}$ \\
\hline Marketinfo & $\begin{array}{l}0.0102 \\
(0.015) \\
\end{array}$ & $\begin{array}{c}-0.0130 \\
(0.020) \\
\end{array}$ & $\begin{array}{l}0.0006 \\
(0.015) \\
\end{array}$ & $\begin{array}{l}0.0030 \\
(0.021) \\
\end{array}$ & $\begin{array}{l}0.0162 \\
(0.034) \\
\end{array}$ & $\begin{array}{c}-0.0020 \\
(0.025) \\
\end{array}$ & $\begin{array}{c}-0.0104 \\
(0.019) \\
\end{array}$ & $\begin{array}{l}0.0133 \\
(0.029) \\
\end{array}$ \\
\hline Otherinfo & $\begin{array}{l}0.0082 \\
(0.019)\end{array}$ & $\begin{array}{l}0.0131 \\
(0.027)\end{array}$ & $\begin{array}{l}0.0109 \\
(0.019)\end{array}$ & $\begin{array}{l}0.0182 \\
(0.028)\end{array}$ & $\begin{array}{c}0.1464^{* * *} \\
(0.046)\end{array}$ & $\begin{array}{c}-0.0242 \\
(0.035)\end{array}$ & $\begin{array}{l}0.0029 \\
(0.024)\end{array}$ & $\begin{array}{c}-0.0449 \\
(0.038)\end{array}$ \\
\hline Obs & 2097 & 1244 & 2236 & 1105 & 422 & 537 & 1133 & 608 \\
\hline
\end{tabular}

Note: $\left({ }^{*}\right)$ significant at the $10 \%$ level of significance; $\left({ }^{* *}\right)$ significant at the $5 \%$ level of significance; $\left({ }^{* *}\right)$ significant at the $1 \%$ level of significance.

Concerning size, some determinants to eco-innovate are common to both types of firms, suggesting the relevance of energy and material cost savings due to innovation and environmental regulation. However, clear differences can be observed.

Some features and determinants are specific to small firms. First, the firms are more influenced by internal and external information flows when eco-innovating (INTERINFO AND INSTINFO). The difficulty to find innovation partnerships (NOPARTNER) and lack of qualified staff as a barrier to innovation (NOSTAFF) are an obstacle to eco-innovate for small firms, but not for large firms. Small firms belonging to private companies with foreign equity are more likely to eco-innovate (OWNER). They benefit from the innovation capabilities, financial resources and information flowing from the parent company. These results suggest that lack of internal innovation capabilities and involvement in knowledge networks are a main barrier to eco-innovate by these firms. 
On the other hand, our results show that in contrast to what it is generally argued about the lack of financial capability of small firms being a barrier to eco-innovation, neither lack of internal and external funding (NOFUN) nor a poor financial situation (ROEMPLOYEE) are barriers to eco-innovate for small firms with respect to normal innovation. The positive sign and statistical significance of public subsidies (PUBLICAID) suggest that, in fact, public funds (which are not specifically provided to eco-innovate) are being effective for small firms to eco-innovate. In other words, firms may not perceive those financial barriers due to the availability of those funds. Overall, these results allow us to (partly) reject hypothesis (i).

Regarding firm age, new ones are not more eco-innovative than older ones, as shown by the lack of significance of AGE as a regressor. Therefore, hypothesis (ii) can be rejected. This finding is against the common statement that new firms are necessarily more eco-innovative (see section 1.2) when the empirical literature is not conclusive in this regard (see Tables 1 and 2).

Knowledge capital accumulated by the firm though R\&D (INTERD) or knowledge flows from the parent company (OWNER) or as a result of cooperation (COOPERATION) are a main driver for new firms to eco-innovate, in contrast to older firms. Thus, internal innovation capacity and cooperation are more relevant for new firms to eco-innovate compared to old firms, i.e., hypothesis (iii) can not be rejected.

A few determinants are a common driver to both NTF vs. NTM eco-innovations: environmental regulation (REGULATION) and unitary material and energy cost savings (SAVINGS). However, in contrast to NTF eco-innovations, the innovation objective "wider product lines" (WIDERANGE) is a main driver of NTM eco-innovations, i.e., these eco-innovations tend to increase the types of products being offered by the firm. However, compared to normal innovation, eco-innovation is not regarded as a way to access new consumers in existing or new markets, i.e. a demand-pull from the market is not perceived and is not a driver neither for NTF nor NTM eco-innovation. Thus, hypothesis (v) can be rejected.

Since NTM eco-innovations can be regarded as more radical, complex, systemic or disruptive than NTF eco-innovation, the features and determinants should be different for both eco-innovations types. We could expect that NTM eco-innovations would require greater internal and external innovation capabilities. Our results show that NTF eco-innovations do not require high internal innovation capabilities and knowledge flows from external sources with respect to general NTF innovation (i.e., lack of significance of INTERD, COOPERATION and INSTINFO). In contrast, internal innovation capabilities (INTERD), external knowledge sources (INSTINFO) and a sound financial situation (ROEMPLOYEE) are relevant drivers for NTM eco-innovations. This confirms hypothesis (iv).

Finally, the results show that there are a few differential drivers of product and process eco-innovations. Both eco-innovation types are positively affected by internal R\&D investments (INTERD) and cooperation (COOPERATION). External knowledge flows from knowledge institutions (INSTINFO) are relevant only for product eco-innovations, whereas knowledge flows internal to the firm (INTERINFO) are a driver of process eco-innovations. This suggests that product eco-innovations do not require greater internal innovation capabilities and cooperation, i.e., hypothesis (vi) should be rejected. 
Contrary to expectations, energy/material cost reductions (SAVINGS) and environmental regulation (REGULATION) influence both product and process eco-innovations. The demand-pull from the market is absent for product (and also for process) eco-innovations, i.e., hypothesis (vii) should be rejected. Thus, eco-innovations are not regarded as a way to penetrate new markets or increase quotas in existing markets. This lack of a demand-pull from the market could be attributed to the special features of Spain regarding the willingness to pay for eco-products and consciousness of its consumers. Although the environmental consciousness of consumers is an important characteristic of demand for product eco-innovations (see section 1), the relatively low willingness-to-pay of Spanish consumers for eco-friendly products (as shown by EC 2011: 157) may explain the lack of statistical significance of the demand-pull variable. This result is in line with previous research on drivers to eco-innovation or corporate environmental performance in Spain (see del Río 2005; del Río et al. 2015; Cabezudo et al. 2000; Aragón Correa 1998). See Peñasco and del Río (2013) for a review of studies on the determinants to eco-innovation in Spanish firms.

Table 5 summarizes the above discussion.

Table 5. Rejection of hypotheses

\begin{tabular}{|c|c|}
\hline Hypothesis & Rejection \\
\hline \multicolumn{2}{|l|}{ Size } \\
\hline $\begin{array}{l}\text { (i) Public subsidies and involvement in internal and external information flows } \\
\text { have a greater effect on small firms. }\end{array}$ & Partly \\
\hline
\end{tabular}

\begin{tabular}{|c|c|}
\hline \multicolumn{2}{|l|}{ Age } \\
\hline (ii) New firms are more eco-innovative. & Yes \\
\hline (iii) Internal innovation capacity and cooperation are more relevant for new firms. & No \\
\hline \multicolumn{2}{|l|}{ NTM/NTF } \\
\hline $\begin{array}{l}\text { (iv) Internal innovation capabilities, a sound financial situation and information } \\
\text { flows from knowledge institutions are less relevant for NTF eco-innovations. }\end{array}$ & No \\
\hline $\begin{array}{l}\text { (v) NTM eco-innovations are deployed to access new markets or new clients } \\
\text { in existing markets, whereas compliance with environment regulation and } \\
\text { cost-savings are a main driver of NTF eco-innovations. }\end{array}$ & Yes \\
\hline \multicolumn{2}{|l|}{ Product/process } \\
\hline $\begin{array}{l}\text { (vi) Product eco-innovations require greater internal innovation capabilities } \\
\text { and cooperation. }\end{array}$ & Yes \\
\hline $\begin{array}{l}\text { (vii) Process eco-innovations are more driven by environmental regulation } \\
\text { and cost-savings, whereas product eco-innovations are driven by the market-pull. }\end{array}$ & Yes \\
\hline
\end{tabular}

\section{Conclusions}

This paper has analysed the main determinants influencing eco-innovators versus non-ecoinnovators in Spain, considering different eco-innovation and eco-innovator types.

The environmental regulation variable is a main driver for all eco-innovation and eco-innovator types, whereas another public policy, i.e., grants, are only a driver for small and old eco-innovators, and do not seem to encourage any eco-innovation type. 
Other drivers are particularly relevant for certain eco-innovation or eco-innovator types. Our results suggest that this is the case of internal innovation capabilities, involvement in external knowledge flows and cooperation which are important for given eco-innovator/ eco-innovation types. Internal innovation capabilities clearly influence small and new firms to eco-innovate, vs. large and old firms. Those capabilities are also a driver of NTM with respect to NTF eco-innovation. Involvement in external knowledge flows and cooperation is a crucial variable for small firms to eco-innovate and a driver for NTM eco-innovation.

Unexpectedly, there are a few differential drivers for product vs. process eco-innovation. Energy/material cost reductions and environmental regulation influence both eco-innovation types, whereas the demand-pull from the market is absent for both. The lack of a demand-pull from the market is attributed to the special features of Spain regarding the willingness to pay for eco-products and consciousness of its consumers. Also unexpectedly, product eco-innovations do not require greater internal innovation capabilities than process eco-innovations. External knowledge flows from knowledge institutions are relevant only for product eco-innovations, whereas knowledge flows internal to the firm are a driver of process eco-innovations.

Overall, these results suggest that a combination of environmental regulation and targeted policy instruments is likely to be effective to trigger eco-innovation, by addressing the different drivers for distinct eco-innovation and eco-innovator types. In general, public policies enhancing internal innovation capabilities, cooperation and knowledge flows are highly effective in influencing most eco-innovation/eco-innovator types. This could be done by providing firm-level support to upgrade the skills of companies. Encouraging networking, i.e., promoting public-private collaboration (through public-private partnerships in $\mathrm{R} \& \mathrm{D}$ and innovation) and cooperation between firms and knowledge institutions (i.e., universities and research centres) triggers some eco-innovation and eco-innovator types directly (by providing the required knowledge) but also indirectly (by enhancing the internal capabilities of firms). According to our results, these instruments would be particularly effective to encourage small and new firms to eco-innovate and NTM eco-innovation. In contrast to environmental regulation, grants specifically targeted at eco-innovation do not seem to be justified, except only to induce small and old firms to eco-innovate. The significance of the cost-savings variable for all eco-innovator and eco-innovation types suggests that instruments which make firms aware of cost-saving eco-innovation opportunities (for example, through the creation of clearinghouses) would be particularly effective in this context, especially for SMEs. Indeed, the fact that SMEs are much less eco-innovative than larger firms might be related to lack of information on the existence of cost-saving eco-innovations (del Río et al. 2015), as shown in the past by del Río (2005).

Our results suggest that, if the aim is to support specific eco-innovation or eco-innovator types, some instruments could be quite effective. This specific targeting of instruments has in the past been justified for small and new firms and for NTM eco-innovations. If, as suggested by our results, it is true that small firms have more difficulties to eco-innovate than their larger counterparts (Kammerer 2009), then environmental regulation, grants, information campaigns on cost savings, and facilitating the integration of small firms in external knowledge flows would be appropriate instruments. If NTM are more radical than NTF eco-innovations and, thus, bring potentially higher environmental benefits (OECD 
2009; Tukker, Butler 2007; Smith et al. 2005), then they should be supported with environmental regulation, encouraging the accumulation of internal innovation capabilities in firms and supporting integration in external knowledge flows, whereas providing information on cost savings and giving grants would be clearly much less effective. In contrast, according to our analysis, it is not clear that differential support should be provided for process vs. product eco-innovation, given that there are few differential barriers for each eco-innovation type. Finally, our results suggest that, contrary to the claims of some authors, but in line with previous econometric research (see 1.1), new firms are not more eco-innovative than old ones. If it is the aim of policy-makers to encourage eco-innovations in new firms, then environmental regulation, support for internal innovation capabilities, information on cost savings and supporting cooperation would be suitable instruments in this regard, whereas environmental regulation, grants, up-front costs savings and facilitating the integration of firms in external knowledge flows are more appropriate to encourage eco-innovation in incumbent firms.

\section{References}

Acemoglu, D.; Cao, D. 2015. Innovation by entrants and incumbents, Journal of Economic Theory 157: 255-294. http://dx.doi.org/10.1016/j.jet.2015.01.001

Almus, M.; Czarnitzki, D. 2003.The effects of public R\&D subsidies on firms innovation activities, Journal of Business and Economic Statistics 21(2): 226-236. http://dx.doi.org/10.1198/073500103288618918

Andersen, M. 2011. Into the green economy eco-innovation dynamics and policy challenges, in UN Conference Promoting Eco-innovation: Policies and Opportunities, 13 November 2011, Tel Aviv, Israel [online], [cited March 2013]. Available from Internet: http://www.unece.org/fileadmin/DAM/ceci/ ppt_presentations/2011/Israel_ICP/Andersen.pdf

Aragón-Correa, J. A. 1998. Strategic proactivity and firm approach to the natural environment, The Academy of Management Journal 41(5): 556-567. http://dx.doi.org/10.2307/256942

Azofra, M. J. 1999. Cuestionarios. Cuadernos Metodológicos 26. Centro de Investigaciones Sociológicas. $144 \mathrm{p}$.

Baumol, W. J. 2002. The free-market innovation machine - analyzing the growth miracle of capitalism. Princeton, NJ: Princeton University Press, 318 p. http://dx.doi.org/10.1515/9781400851638

Bergek, A.; Jacobsson, S.; Carlsson, B.; Lindmark, S.; Rickne, A. 2008. Analyzing the functional dynamics of technological innovation systems - a scheme of analysis, Research Policy 37(3): 407-429. http://dx.doi.org/10.1016/j.respol.2007.12.003

Borghesi, S.; Cainelli, G.; Mazzanti, M. 2012a. The European emission trading scheme and environmental innovation: empirical analyses using data for Italy, Giornale degli Economisti e Annali di Economia 71(1): 71-97.

Borghesi, S.; Cainelli, G.; Mazzanti, M. 2012b. Brown sunsets and green dawns in the industrial sector: environmental innovations, firm behaviour and the European Emission trading, Fondazione Eni Enrico Mattei (FEEM) Nota di Lavoro 3.2012 [online], [cited February 2013]. Available from Internet: http://www.feem.it/getpage.aspx?id=4575\&sez=Publications\&padre $=73$

Cabezudo, S.; del Río, P.; Cadenas, A. 2000. Las fuerzas del cambio empresarial en medioambiente, in Hacia un Desarrollo Económico y Medioambiental Sostenible, EkonomiGerizan 7, Cajas de Ahorros Vasco Navarras, 155-174.

Cainelli, G.; Mazzanti, M. 2013. Environmental innovations in services: manufacturing-services integration and policy transmissions, Research Policy 42: 1595-1604.

http://dx.doi.org/10.1016/j.respol.2013.05.010 
Cainelli, G.; Mazzanti, M.; Montresor, S. 2012. Environmental innovations, local networks and internationalization, Industry and Innovation 19: 697-734. http://dx.doi.org/10.1080/13662716.2012.739782

Carrillo-Hermosilla, J.; del Río, P.; Könnölä, T. 2010. Diversity of eco-innovations: reflections from selected case studies, Journal of Cleaner Production 18 (10-11): 1073-1083. http://dx.doi.org/10.1016/j. jclepro.2010.02.014

Cleff, T.; Rennings, K. 1999. Determinants of environmental product and process innovation, European Environment 9: 191-201.

http://dx.doi.org/10.1002/(SICI)1099-0976(199909/10)9:5<191::AID-EET201>3.0.CO;2-M

De Marchi, V. 2012. Environmental innovation and R\&D cooperation: empirical evidence from Spanish manufacturing firms, Research Policy 41: 614-623. http://dx.doi.org/10.1016/j.respol.2011.10.002

Del Río, P. 2005. Analysing the factors influencing clean technology adoption: a study of the Spanish pulp and paper industry, Business Strategy and the Environment 14: 20-37. http://dx.doi.org/10.1002/bse.426

Del Río, P. 2009. The empirical analysis of the determinants for environmental technological change: a research agenda, Ecological Economics 68: 861-878. http://dx.doi.org/10.1016/j.ecolecon.2008.07.004

Del Río, P., Tarancón, M. Á., Callejas, F. 2011. Analysing the determinants of environmental technology investments. A panel-data study of Spanish industrial sectors, Journal of Cleaner Production 19(11): 1170-1179. http://dx.doi.org/10.1016/j.jclepro.2010.05.001

Del Río, P.; Peñasco, C.; Romero-Jordán, D. 2015. Distinctive features of environmental innovators: an econometric analysis, Business Strategy and the Environment 24(6): 361-385. http://dx.doi.org/10.1002/bse.1822

Demirel, P.; Kesidou, E. 2011. Stimulating different types of eco-innovation in the UK: government policies and firm motivations, Ecological Economics 70(8): 1546-1557. http://dx.doi.org/10.1016/j.ecolecon.2011.03.019

Díaz-López, F. J. 2008. A tailored method for eco-innovation strategies and drivers (in the South), Paper Submitted to the DIME International Conference Innovation, Sustainability and Policy, 11-13 September 2008, GrethA.University Montesquieu Bordeaux IV, France.

European Commission (EC). 2011. Attitudes of European citizens towards the environment [online]. Special Eurobarometer 365 [cited March 2013]. Available from Internet: http://ec.europa.eu/environment/pdf/ebs_365_en.pdf

Frondel, M.; Horbach, J.; Rennings, K. 2007.End-of-pipe or cleaner production? An empirical comparison of environmental innovation decisions across OECD countries, Business Strategy and the Environment 16(8): 571-584. http://dx.doi.org/10.1002/bse.496

Greene, W. H. 2008. Econometric analysis. 6th ed. Pearson International, Upper Saddle River, 1216 p.

Horbach, J. 2008. Determinants of environmental innovation - new evidence from German panel data sources, Research Policy 37(1): 163-173. http://dx.doi.org/10.1016/j.respol.2007.08.006

Horbach, J.; Rammer, C.; Rennings, K. 2012. Determinants of eco-innovations by type of environmental impact - the role of regulatory push/pull, technology push and market pull, Ecological Economics 78: 112-122. http://dx.doi.org/10.1016/j.ecolecon.2012.04.005

Horbach, J.; Oltra, V.; Belin, J. 2013. Determinants and specificities of eco-innovations - an econometric analysis for the French and German industry based on the community innovation survey, Industry and Innovation 20(6): 523-543. http://dx.doi.org/10.1080/13662716.2013.833375

Inoue, E.; Arimura, T.; Nakano, M. 2013. A new insight into environmental innovation: does the maturity of environmental management systems matter?, Ecological Economics 94: 156-163. http://dx.doi.org/10.1016/j.ecolecon.2013.07.014

ISO. 2004. Environmental management systems - General guidelines on principles, systems and support techniques. ISO 14001:2004. Technical Committee ISO/TC 207, Environmental management, Subcommittee SC 1, Environmental management systems, Switzerland. 
ISO. 2008. Quality management systems - Requirements. ISO 9001:2008. Technical Committee ISO/TC 176, Quality management and quality assurance, Subcommittee SC 2, Quality systems, Switzerland.

Kammerer, D. 2009. The effects of customer benefit and regulation on environmental product innovation: empirical evidence from appliance manufacturers in Germany, Ecological Economics 68(8-9): 2285-2295. http://dx.doi.org/10.1016/j.ecolecon.2009.02.016

Kesidou, E.; Demirel, P. 2012. On the drivers of eco-innovations: empirical evidence from the UK, Research Policy 41(5): 862-870. http://dx.doi.org/10.1016/j.respol.2012.01.005

Mazzanti, M.; Zoboli, R. 2009. Embedding environmental innovation in local production systems: SME strategies, networking and industrial relations: evidence on innovation drivers in industrial districts, International Review of Applied Economics 23(2): 169-195.

http://dx.doi.org/10.1080/02692170802700500

OECD. 2009. Sustainable manufacturing and eco-innovation. Framework, practices and measurement. Synthesis report [online], [cited March 2013]. OECD Publishing, Paris. Available from Internet: http://www.oecd.org/innovation/inno/43423689.pdf

OECD. 2011. Better policies to support eco-innovation: OECD studies on environmental innovation. OECD Publishing, Paris. http://dx.doi.org/10.1787/9789264096684-en

Oltra, V. 2008. Environmental innovation and industrial dynamics: the contributions of evolutionary economics. Working Papers Cahiers du GrethA 2008-28 [online], [cited March 2013]. Available from Internet: http://ideas.repec.org/p/grt/wpegrt/2008-28.html

Ormazábal, M.; Sarriegi, J. M. 2014. Environmental management evolution: empirical evidence from Spain and Italy, Business Strategy and the Environment 23(2): 73-88. http://dx.doi.org/10.1002/bse.1761

Peñasco, C.; Del Río, P. 2013. La innovación ambiental en España. Determinantes e implicaciones para las políticas públicas, Panorama Social 18: 91-104.

PITEC. 2007. La base de datos Panel de Innovación Tecnológica (PITEC). Fundación Española para la Ciencia y la Tecnología. Ministerio de Economía y Competitividad.

Rave, T.; Goetzke, F.; Larch, M. 2011. The determinants of environmental innovations and patenting: Germany reconsidered. Ifo Working Paper 97.

Rehfeld, K.; Rennings, K.; Ziegler, A. 2007. Integrated product policy and environmental product innovations: an empirical analysis, Ecological Economics 61(1): 91-100. http://dx.doi.org/10.1016/j.ecolecon.2006.02.003

Rennings, K. 2000. Redefining innovation - eco-innovation research and the contribution from ecological economics, Ecological Economics 32: 319-332. http://dx.doi.org/10.1016/S0921-8009(99)00112-3

Rennings, K.; Rammer, C. 2009. Increasing energy and resource efficiency through innovation - an explorative analysis using innovation survey data, Czech Journal of Economics and Finance 59(5): 442-459. http://dx.doi.org/10.2139/ssrn.1495761

Rennings, K.; Ziegler, A.; Ankele, K.; Hoffmann, E. 2006. The influence of different characteristics of the EU environmental management and auditing scheme on technical environmental innovation and economic performance, Ecological Economics 57(1): 45-59. http://dx.doi.org/10.1016/j.ecolecon.2005.03.013

Rosenberg, N. 1974. Science, invention and economic growth, The Economic Journal 84: 90-108. http://dx.doi.org/10.2307/2230485

Smith, A.; Stirling, A.; Berkhout, F. 2005. The governance of sustainable sociotechnical transitions, Research Policy 34: 1491-1510. http://dx.doi.org/10.1016/j.respol.2005.07.005

Triguero, A.; Moreno-Mondéjar, L.; Davia, M. A. 2013. Drivers of different types of eco-innovation in European SMEs, Ecological Economics 92(1): 25-33. http://dx.doi.org/10.1016/j.ecolecon.2013.04.009

Tukker, A.; Butter, M. 2007. Governance of sustainable transitions: about the 4(0) ways to change the world, Journal of Cleaner Production 15(1): 94-103. http://dx.doi.org/10.1016/j.jclepro.2005.08.016 
United Nations Economic Commission for Europe (UNECE). 2011. International conference Promoting Eco-innovation: Policies and Opportunities, 11-13 July 2011, Tel Aviv, Israel [online], [cited February 2013]. Available from Internet: http://www-imece-prg/indez.php?id=14913

Veugelers, R. 2012. Which policy instruments to induce clean innovating?, Research Policy 41: 17701778. http://dx.doi.org/10.1016/j.respol.2012.06.012

Wagner, M. 2007. On the relationship between environmental management, environmental innovation and patenting: evidence from German manufacturing firms, Research Policy 36: 1587-1602. http://dx.doi.org/10.1016/j.respol.2007.08.004

Wagner, M. 2008. Empirical influence of environmental management on innovation: evidence from Europe, Ecological Economics 66: 392-402. http://dx.doi.org/10.1016/j.ecolecon.2007.10.001

Walz, R. 2011. Opportunities and specific challenges for eco-innovations, in UN conference Promoting Eco-innovation: Policies and Opportunities, 11-13 July 2011, Tel Aviv, Israel [online], [cited February 2013]. Available from Internet: http://www.unece.org/gileadmin/DAM/ceci/ppt_presentations/2011/Israel_ICP/Walz.pdf

Ziegler, A.; Rennings, K. 2004. Determinants of environmental innovations in Germany: do organizational measures matter? ZEW - Centre for European Economic Research Discussion Paper No. 04-030. http://dx.doi.org/10.2139/ssrn.552082

\section{APPENDIX}

\section{Description of variables}

Table A1. Number of firms per activity branch in the sample

\begin{tabular}{llcc}
\hline Code & \multicolumn{1}{c}{ Activity branch } & CNAE-2009 & Firms \\
\hline 0001 & mining and extractive industries & 05, 06, 07, 08, 09 & 18 \\
\hline 0002 & oil industry & 19 & 2 \\
\hline 0003 & food, beverages and tobacco & $10,11,12$ & 418 \\
\hline 0004 & textile & 13 & 112 \\
\hline 0005 & manufacturing wearing apparel & 14 & 39 \\
\hline 0006 & leather and footwear & 15 & 25 \\
\hline 0007 & wood and corck & 16 & 46 \\
\hline 0008 & pulp, paper and cardboard & 17 & 57 \\
\hline 0009 & printing & 18 & 34 \\
\hline 0010 & chemical industry & 20 & 430 \\
\hline 0011 & pharmaceutical industry & 21 & 134 \\
\hline 0012 & rubber and plastic products & 22 & 204 \\
\hline 0013 & non-metallic mineral products & 23 & 151 \\
\hline 0014 & basic metals & 24 & 104 \\
\hline 0015 & metal processing & 25 & 297 \\
\hline 0016 & manuf. of TIC, medical and precision & 26 & 227 \\
\hline 0017 & electrical machinery and equipment & 27 & 195 \\
\hline 0018 & other machinery and equipment & 28 & 447 \\
\hline & & & \\
\hline
\end{tabular}


End of Table A1

\begin{tabular}{llcc}
\hline Code & \multicolumn{1}{c}{ Activity branch } & CNAE-2009 & Firms \\
\hline 0019 & motor vehicles & 29 & 171 \\
\hline 0020 & ship building & 301 & 14 \\
\hline 0021 & aircraft and spacecraft & 303 & 14 \\
\hline 0022 & other transport equipment & 30 & (exc. 301, 303)20 \\
\hline 0023 & furniture & 31 & 96 \\
\hline 0024 & other manufacturing activities & 32 & 86 \\
\hline TOTAL & & & 3341 \\
\hline
\end{tabular}

Table A2. Summary statistics and description of the variables used in the estimations

\begin{tabular}{|c|c|c|c|c|}
\hline Code & Description of variables & Values & Mean & $\begin{array}{c}\text { Std. } \\
\text { Deviation }\end{array}$ \\
\hline HEI & Dependent: Environmental Innovators & $\begin{array}{l}1 \text { High importance } \\
\text { of reducing } \\
\text { environmental impact } \\
0 \text { Otherwise }\end{array}$ & 0.284 & 0.451 \\
\hline AGE & Time since company foundation & Years & 30.354 & 20.223 \\
\hline SIZE & Employees & Number of employees & 193.524 & 528.717 \\
\hline INTERNATIONAL & $\begin{array}{l}\text { Product sales in domestic } \\
\text { or international markets }\end{array}$ & $\begin{array}{l}1 \text { International } \\
\text { markets } \\
0 \text { Only national } \\
\text { market }\end{array}$ & 0.879 & 0.326 \\
\hline INTERD & $\begin{array}{l}\text { Internal R\&D expenditures } \\
\text { (as \% of innovation expenditures) }\end{array}$ & $\%$ & 65.951 & 35.514 \\
\hline \multicolumn{5}{|c|}{ Barriers to innovation } \\
\hline NOFUN & $\begin{array}{l}\text { Lack of internal or/and external funds } \\
\text { as a barrier to innovation }\end{array}$ & $\begin{array}{l}1 \text { High importance } \\
0 \text { Otherwise }\end{array}$ & 0.446 & 0.497 \\
\hline HIGHIVCOST & $\begin{array}{l}\text { High innovation costs as a barrier } \\
\text { to innovation }\end{array}$ & $\begin{array}{l}1 \text { High importance } \\
0 \text { Otherwise }\end{array}$ & 0.347 & 0.476 \\
\hline NOSTAFF & $\begin{array}{l}\text { Lack of qualified staff as a barrier } \\
\text { to innovation }\end{array}$ & $\begin{array}{l}1 \text { High importance } \\
0 \text { Otherwise }\end{array}$ & 0.098 & 0.297 \\
\hline NOTECINFO & $\begin{array}{l}\text { Lack of information about new } \\
\text { technology }\end{array}$ & $\begin{array}{l}1 \text { High importance } \\
0 \text { Otherwise }\end{array}$ & 0.080 & 0.271 \\
\hline NOMARKINFO & Lack of information about new markets & $\begin{array}{l}1 \text { High importance } \\
0 \text { Otherwise }\end{array}$ & 0.091 & 0.287 \\
\hline NOPARTNER & $\begin{array}{l}\text { Difficulty to find innovation } \\
\text { partnerships }\end{array}$ & $\begin{array}{l}1 \text { High importance } \\
0 \text { Otherwise }\end{array}$ & 0.099 & 0.299 \\
\hline ESTFIRMS & $\begin{array}{l}\text { Existence of a market dominated } \\
\text { by established firms }\end{array}$ & $\begin{array}{l}1 \text { High importance } \\
0 \text { Otherwise }\end{array}$ & 0.205 & 0.404 \\
\hline UNCERTD & $\begin{array}{l}\text { Uncertainty on the demand for } \\
\text { innovative products }\end{array}$ & $\begin{array}{l}1 \text { High importance } \\
0 \text { Otherwise }\end{array}$ & 0.274 & 0.446 \\
\hline PASTIV & Prior innovation in the firm & $\begin{array}{l}1 \text { High importance } \\
0 \text { Otherwise }\end{array}$ & 0.021 & 0.144 \\
\hline NODEMAND & Lack of demand for innovative products & $\begin{array}{l}1 \text { High importance } \\
0 \text { Otherwise }\end{array}$ & 0.025 & 0.157 \\
\hline \multicolumn{5}{|c|}{ Aim of innovation } \\
\hline WIDERANGE & Increasing the range of products & $\begin{array}{l}1 \text { High importance } \\
0 \text { Otherwise }\end{array}$ & 0.528 & 0.499 \\
\hline
\end{tabular}


End of Table A2

\begin{tabular}{|c|c|c|c|c|}
\hline Code & Description of variables & Values & Mean & $\begin{array}{c}\text { Std. } \\
\text { Deviation }\end{array}$ \\
\hline REPLACE & Replacing old products or process & $\begin{array}{l}1 \text { High importance } \\
0 \text { Otherwise }\end{array}$ & 0.351 & 0.477 \\
\hline MARKET & $\begin{array}{l}\text { Increasing market share by different } \\
\text { means }\end{array}$ & $\begin{array}{l}1 \text { High importance } \\
0 \text { Otherwise }\end{array}$ & 0.528 & 0.499 \\
\hline PQUALITY & Increasing the quality of products & $\begin{array}{l}1 \text { High importance } \\
0 \text { Otherwise }\end{array}$ & 0.525 & 0.499 \\
\hline PROCESSES & Improving production processes & $\begin{array}{l}1 \text { High importance } \\
0 \text { Otherwise }\end{array}$ & 0.424 & 0.494 \\
\hline SAVINGS & $\begin{array}{l}\text { Reducing feedstock and/or energy and } \\
\text { or labour costs per unit output }\end{array}$ & $\begin{array}{l}1 \text { High importance } \\
0 \text { Otherwise }\end{array}$ & 0.363 & 0.481 \\
\hline \multicolumn{5}{|c|}{ Information sources for innovation } \\
\hline INSTINFO & Importance of knowledge institutions & $\begin{array}{l}1 \text { High importance } \\
0 \text { Otherwise }\end{array}$ & 0.226 & 0.418 \\
\hline INTERINFO & $\begin{array}{l}\text { Importance of internal information } \\
\text { sources from the company }\end{array}$ & $\begin{array}{l}1 \text { High importance } \\
0 \text { Otherwise }\end{array}$ & 0.654 & 0.476 \\
\hline MARKETINFO & $\begin{array}{l}\text { Importance of market players } \\
\text { information }\end{array}$ & $\begin{array}{l}1 \text { High importance } \\
0 \text { Otherwise }\end{array}$ & 0.467 & 0.499 \\
\hline OTHERINFO & $\begin{array}{l}\text { Importance of other information } \\
\text { sources }\end{array}$ & $\begin{array}{l}1 \text { High importance } \\
0 \text { Otherwise }\end{array}$ & 0.174 & 0.379 \\
\hline \multicolumn{5}{|c|}{ Other variables } \\
\hline PUBLICAID & $\begin{array}{l}\text { Public subsidies received from local, } \\
\text { regional or central governments or } \\
\text { from the EU. }\end{array}$ & $\begin{array}{l}1 \text { The firm has } \\
\text { received subsidies } \\
0 \text { The firm has not } \\
\text { received subsidies }\end{array}$ & 0.476 & 0.499 \\
\hline EXTKNOW & $\begin{array}{l}\text { External knowledge acquisition } \\
\text { expenditures (as a percentage of } \\
\text { innovation expenditures) }\end{array}$ & $\%$ & 0.618 & 6.240 \\
\hline TECHOPPORT & $\begin{array}{l}\text { The firm belongs to a high-technology } \\
\text { sector. }\end{array}$ & $\begin{array}{l}1 \text { Yes } \\
0 \text { No }\end{array}$ & 0.516 & 0.500 \\
\hline PAT & Patent applications (2007-2009) & $\begin{array}{l}1 \text { Patent applicant firm } \\
0 \text { No patent applicant } \\
\text { firm }\end{array}$ & 0.173 & 0.379 \\
\hline ROEMPLOYEE & $\begin{array}{l}\text { Company turnover/number of } \\
\text { employees }\end{array}$ & $€ /$ employee & 228297.4 & 377749.5 \\
\hline OWNER & Company type & $\begin{array}{l}1 \text { private company } \\
\text { without foreign equity } \\
2 \text { private company } \\
\text { with foreign equity }\end{array}$ & 1.195 & 0.396 \\
\hline TURNVAR & Turnover change 2008-2009 & $\%$ & -12.364 & 58.273 \\
\hline REGULATION & $\begin{array}{l}\text { Importance of compliance with } \\
\text { environmental, health and safety } \\
\text { regulations as an aim of innovation }\end{array}$ & $\begin{array}{l}1 \text { High } \\
0 \text { Otherwise }\end{array}$ & 0.349 & 0.477 \\
\hline COOPERATION & Participation in innovation cooperation & $\begin{array}{l}1 \text { Non-cooperative } \\
\text { company } \\
2 \text { Cooperative } \\
\text { company between } \\
2006-2008 \text { or between } \\
2007-2009 \\
3 \text { Cooperative } \\
\text { company between } \\
2006-2009\end{array}$ & 1.777 & 0.898 \\
\hline
\end{tabular}

Note: All variables refer to 2009, unless stated otherwise. 


\begin{tabular}{|c|c|c|c|c|c|c|c|c|c|c|c|c|c|c|c|c|c|c|c|c|c|c|c|c|c|c|c|c|c|c|c|c|c|}
\hline OANIYAHLO & & & & & & & & & & & & & & & & & & & & & & & & & & & & & & & & & 实 \\
\hline OANILAYYYWW & & & & & & & & & & & & & & & & & & & & & & & & & & & & & & & & & 蒿 \\
\hline OANIILSNI & & & & & & & & & & & & & & & & & & & & & & & & & & & & & & & $\stackrel{8}{-}$ & & : \\
\hline OANIYALLNI & & & & & & & & & & & & & & & & & & & & & & & & & & & & & & $\stackrel{8}{-}$ & & & 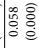 \\
\hline aNVWHAON & & & & & & & & & & & & & & & & & & & & & & & & & & & & & $\stackrel{8}{-}$ & & 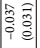 & & 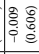 \\
\hline AILSVd & & & & & & & & & & & & & & & & & & & & & & & & & & & & 8 & & & & & \\
\hline S.LYAวNก & & & & & & & & & & & & & & & & & & & & & & & & & & & $\stackrel{-1}{-1}$ & & & & 变 & & 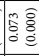 \\
\hline SWYIHLSA & & & & & & & & & & & & & & & & & & & & & & & & & & & & 管: & & & 滵 & & 送 \\
\hline YAN.LAVdON & & & & & & & & & & & & & & & & & & & & & & & & & & & & 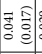 & & & & & 象 \\
\hline OHNILAYYYWON & & & & & & & & & & & & & & & & & & & & & & & & & & & & 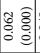 & & & & & 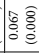 \\
\hline OANIDALION & & & & & & & & & & & & & & & & & & & & & & & 8 & & & & & To & | & & 管高: & & \\
\hline AHVLSON & & & & & & & & & & & & & & & & & & & & & & 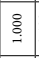 & & & & & & 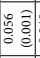 & & & & 9 & \\
\hline LSOJAIHDIH & & & & & & & & & & & & & & & & & & & & & 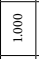 & & & 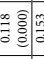 & & & & 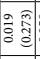 & $\begin{array}{lll}0 \\
0\end{array}$ & & $\begin{array}{l}0 \\
0 \\
0 \\
0 \\
0 \\
0\end{array}$ & & \\
\hline NกAXANION & & & & & & & & & & & & & & & & & & & & & & & & & & & 索 & 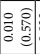 & 党: & & & a & \\
\hline NOILVYAdOOJ & & & & & & & & & & & & & & & & & & & $\stackrel{8}{-}$ & & & & & & & & & 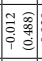 & $\begin{array}{lll}\infty \\
0 \\
0\end{array}$ & & 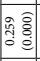 & 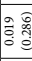 & 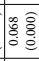 \\
\hline AZIS & & & & & & & & & & & & & & & & & & & 㱐 & & & & 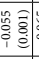 & 党: & & & & 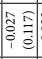 & 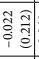 & 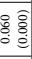 & \begin{tabular}{|c|c|}
0 \\
0 \\
0
\end{tabular} & 袋妻 & \\
\hline SONIAVS & & & & & & & & & & & & & & & & & $\stackrel{8}{\circ}$ & & 急 & : & & 产 & 恖 & & & & 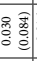 & 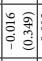 & 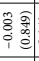 & & & 象 & \\
\hline NOILVTก९AY & & & & & & & & & & & & & & & & 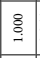 & & & 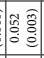 & : & & 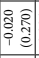 & : & 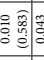 & & & & \begin{tabular}{|c|c|} 
\\
$\vdots$ \\
\hdashline
\end{tabular} & 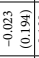 & : & 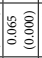 & 绐盘 & \\
\hline SASSAวOYd & & & & & & & & & & & & & & & 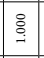 & \begin{tabular}{|l|}
\multirow{2}{*}{} \\
g. \\
\end{tabular} & fo & 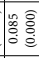 & 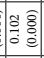 & 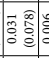 & & 要 & 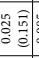 & 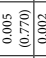 & & & ${ }^{\circ}$ & 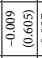 & 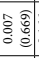 & $\frac{8}{0}$ & : & 局 & \\
\hline X.LITVNÖd & & & & & & & & & & & & & & $\underset{-}{\circ}$ & & & 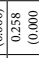 & & & 象象 & & & & 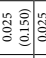 & & & & 要 & $\begin{array}{ll}\infty \\
0 \\
0\end{array}$ & : & & & \\
\hline LAצYYW & & & & & & & & & & & & & $\stackrel{8}{8}$ & & & & : & & : & : & & & & 悹 & & & & 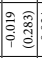 & 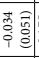 & $\frac{\pi}{0}$ & 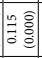 & & \\
\hline घวУTdヨष & & & & & & & & & & & & 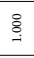 & 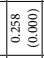 & శ్ & & & 象 & 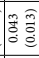 & 20 & {$\left[\begin{array}{lll}0 \\
0 \\
0\end{array}\right.$} & & 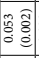 & 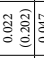 & $\begin{array}{ll} \\
0 \\
0 \\
0\end{array}$ & & & & 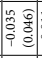 & 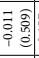 & 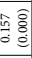 & 然 & 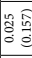 & : \\
\hline aפNVYACIM & & & & & & & & & & & 离 & & {$\left[\begin{array}{l}0 \\
0 \\
0\end{array}\right.$} & & & & 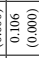 & & 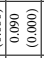 & 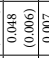 & & & 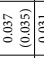 & $\begin{array}{ll} & \text { त् } \\
0 & 0 \\
0 & 0 \\
\end{array}$ & & & & \begin{tabular}{|c|c|} 
\\
0 \\
0 \\
$i$
\end{tabular} & 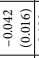 & $\frac{8}{8}$ & 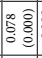 & 然震 & \\
\hline צV & & & & & & & & & & $\stackrel{8}{-}$ & & & 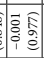 & & & 11 & {$\left[\begin{array}{l}0 \\
0\end{array}\right.$} & & 它 & 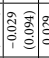 & & & 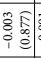 & 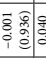 & & & 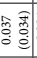 & 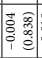 & $\begin{array}{ll}\infty & \text { a } \\
\vdots \\
i\end{array}$ & 列 & 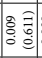 & : & \\
\hline \&تNMO & & & & & & & & & $\underset{-}{\circ}$ & 㝘高: & 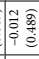 & $\vec{t}$ & 常 & 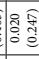 & 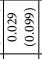 & & 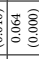 & : & 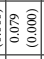 & 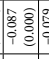 & & $\begin{array}{lll}0 \\
0\end{array}$ & 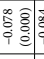 & 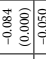 & & & 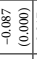 & 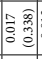 & $\begin{array}{lll}0 & \\
0 \\
0\end{array}$ & 守客 & $\begin{array}{|cc|}0 \\
0 \\
0\end{array}$ & $\begin{array}{ll} \\
\end{array}$ & \\
\hline aมภOTdWHOళ & & & & & & & & $\stackrel{-}{\circ}$ & $\frac{\infty}{0}$ & & & & 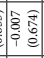 & & & 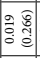 & 递 & & 存 & 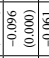 & & & 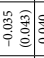 & 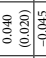 & & 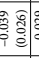 & 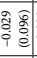 & 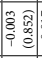 & \begin{tabular}{l}
0 त् \\
$\vdots$ \\
\hdashline
\end{tabular} & 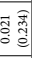 & 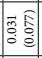 & 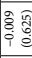 & \\
\hline LVd & & & & & & & $\underset{-}{\stackrel{\Xi}{-}}$ & 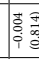 & 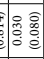 & 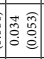 & & है & 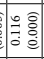 & {$\left[\begin{array}{ll}\infty \\
0 \\
0 \\
0\end{array}\right.$} & & & 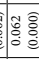 & & 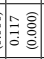 & 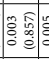 & & & 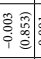 & 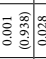 & & & 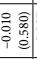 & \begin{tabular}{|c|c|} 
\\
\\
\end{tabular} & 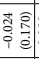 & 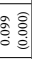 & $\begin{array}{l}\pi \\
\vdots \\
0 \\
0 \\
0\end{array}$ & 震 & \\
\hline aรt & & & & & & 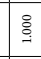 & & & 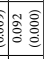 & & & & 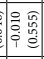 & 旅 & 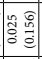 & 4 & 菏 & 西 & 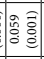 & 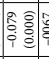 & 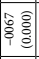 & \begin{tabular}{|l|l} 
\\
\\
\end{tabular} & 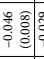 & 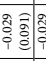 & & 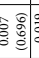 & 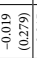 & 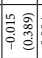 & 商 & : & 㱐 & 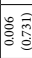 & {$\left[\begin{array}{lll}n \\
0 \\
0\end{array}\right.$} \\
\hline LYOddOHOHL & & & & & $\underset{-8}{8}$ & 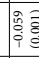 & ริ & & 용 & & & 8 & 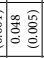 & & & & 을 & 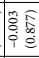 & 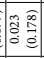 & 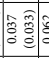 & & 帘 & 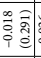 & : & & & 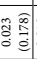 & 辛 & 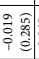 & 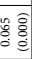 & 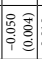 & $\begin{array}{l}0 . \sqrt{0} \\
0\end{array}$ & $\therefore$ \\
\hline TVNOILYNYGLNI & & & & 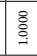 & 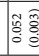 & 80 & 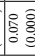 & : & . & 䑾: & & ठृ: & 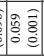 & 常 & $\pi$ क्के & $0 \dot{0}$ & 象事 & to & 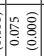 & 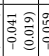 & 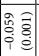 & 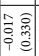 & 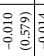 & 感 : & & 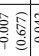 & 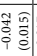 & 产 & $\begin{array}{lll}0 \\
0\end{array}$ & $8 \dot{\theta}$ & $\mid \begin{array}{c}0 \\
\vdots \\
0 \\
0 \\
0\end{array}$ & & \\
\hline MONYLXI & & & \& & 을 & 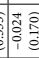 & 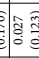 & 8 & 行 & 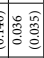 & 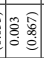 & 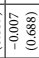 & 吾 & 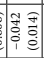 & {$\left[\begin{array}{l}0 \\
\vdots \\
0\end{array}\right.$} & $=$ & 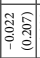 & 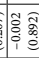 & $\frac{8}{0}$ & 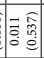 & 㥬 & 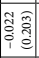 & 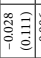 & 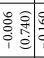 & 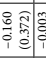 & 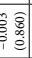 & $\begin{array}{ll}0 \\
\vdots\end{array}$ & 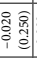 & 管 & 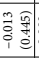 & 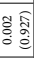 & 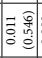 & : & ¿ \\
\hline वषG.LNI & & $\stackrel{8}{-}$ & & & & & & {$\left[\begin{array}{l}0 \\
0 \\
0\end{array}\right.$} & {$\left[\begin{array}{l}0 \\
0 \\
\hdashline \\
\hdashline\end{array}\right.$} & 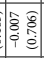 & & $\begin{array}{ll} \\
\end{array}$ & 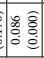 & 要 & 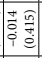 & तs & 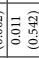 & : & 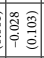 & 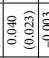 & 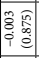 & \begin{tabular}{|l|l|} 
\\
\end{tabular} & 蒡: & 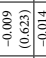 & 索 & 象象 & 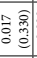 & 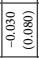 & $\begin{array}{lll} & \\
\end{array}$ & 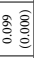 & 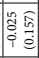 & 话 & \\
\hline बIทวIาgกd & 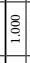 & : & $G$ & & 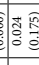 & {$\left[\begin{array}{c}3 \\
0 \\
0\end{array}\right.$} & $\left(\begin{array}{l}n \\
0 \\
0\end{array}\right.$ & : & 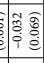 & 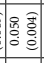 & 急 & 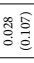 & 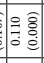 & 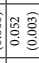 & 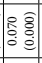 & ఫ్రి & {$\left[\begin{array}{l}0 \\
0 \\
0 \\
0\end{array}\right.$} & $\div$ & 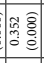 & 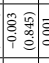 & 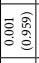 & 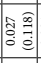 & 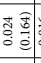 & 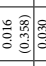 & : & : & 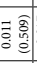 & 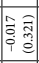 & 吕 & 要: & 韋 & 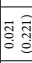 & 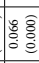 \\
\hline & 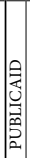 & 啚 & 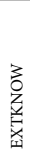 & 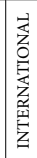 & 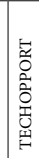 & 䍘 & 岕 & 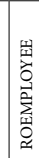 & 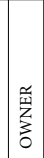 & 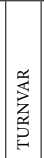 & 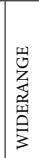 & 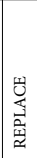 & $\begin{array}{l}\frac{\vec{y}}{2} \\
\frac{2}{2} \\
\frac{2}{2}\end{array}$ & 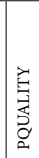 & 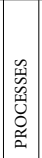 & 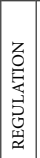 & 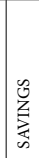 & 选 & 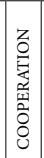 & 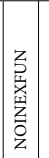 & 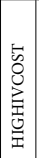 & 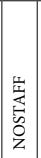 & 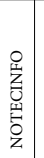 & 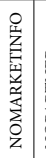 & 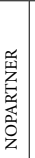 & 总 & 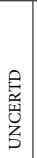 & 络 & 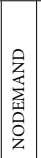 & 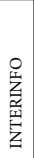 & 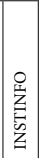 & 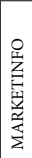 & 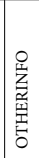 \\
\hline
\end{tabular}


Table A4. Coefficient results of the probit model with instrumental variables

\begin{tabular}{|c|c|c|c|c|c|c|c|c|}
\hline & \multicolumn{2}{|c|}{ Size } & \multicolumn{2}{|c|}{ Age } & \multicolumn{2}{|c|}{ Process/product } & \multicolumn{2}{|c|}{ NTF/NTM } \\
\hline & $\begin{array}{l}\text { small } \\
<100\end{array}$ & $\begin{array}{l}\text { big } \\
\geq 100\end{array}$ & $\begin{array}{c}\text { old } \\
<1990\end{array}$ & $\begin{array}{c}\text { new } \\
\geq 1990\end{array}$ & process & product & NTF & NTM \\
\hline Publicaid & $\begin{array}{c}0.3005^{\star *} \\
(0.143)\end{array}$ & $\begin{array}{c}-0.0571 \\
(0.186)\end{array}$ & $\begin{array}{c}0.2528^{\star} \\
(0.133)\end{array}$ & $\begin{array}{c}-0.0476 \\
(0.213)\end{array}$ & $\begin{array}{l}0.3544 \\
(0.296)\end{array}$ & $\begin{array}{l}0.0211 \\
(0.290)\end{array}$ & $\begin{array}{l}0.2504 \\
(0.225)\end{array}$ & $\begin{array}{l}0.1672 \\
(0.246)\end{array}$ \\
\hline Interd & $\begin{array}{l}0.0030 \\
(0.002)\end{array}$ & $\begin{array}{l}0.0027 \\
(0.002)\end{array}$ & $\begin{array}{l}0.0013 \\
(0.002)\end{array}$ & $\begin{array}{c}0.0056^{\star *} \\
(0.003)\end{array}$ & $\begin{array}{c}0.0098^{* * *} \\
(0.004)\end{array}$ & $\begin{array}{c}0.0109^{\star *} \\
(0.004)\end{array}$ & $\begin{array}{c}-0.0006 \\
(0.002)\end{array}$ & $\begin{array}{c}0.0065^{\star *} \\
(0.003)\end{array}$ \\
\hline Extknow & $\begin{array}{c}-0.0066 \\
(0.008)\end{array}$ & $\begin{array}{l}0.0072 \\
(0.007)\end{array}$ & $\begin{array}{l}0.0025 \\
(0.006)\end{array}$ & $\begin{array}{l}0.0075 \\
(0.007)\end{array}$ & Omitted & $\begin{array}{c}0.0203^{\star *} \\
(0.009)\end{array}$ & $\begin{array}{l}0.0035 \\
(0.006)\end{array}$ & $\begin{array}{l}0.0090 \\
(0.008)\end{array}$ \\
\hline International & $\begin{array}{c}-0.1742 \\
(0.107)\end{array}$ & $\begin{array}{c}-0.1990 \\
(0.174)\end{array}$ & $\begin{array}{c}-0.0780 \\
(0.125)\end{array}$ & $\begin{array}{c}-0.2848^{\star *} \\
(0.134)\end{array}$ & $\begin{array}{c}-0.0374 \\
(0.246)\end{array}$ & $\begin{array}{c}-0.3011 \\
(0.249)\end{array}$ & $\begin{array}{c}-0.2299 \\
(0.156)\end{array}$ & $\begin{array}{c}-0.1845 \\
(0.219)\end{array}$ \\
\hline Techopport & $\begin{array}{c}-0.1779^{* *} \\
(0.076)\end{array}$ & $\begin{array}{c}-0.0584 \\
(0.095)\end{array}$ & $\begin{array}{c}-0.0764 \\
(0.071)\end{array}$ & $\begin{array}{c}-0.2217^{\star \star} \\
(0.101)\end{array}$ & $\begin{array}{c}-0.2836^{\star} \\
(0.166)\end{array}$ & $\begin{array}{c}-0.2865^{\star} \\
(0.170)\end{array}$ & $\begin{array}{c}-0.1793^{\star} \\
(0.105)\end{array}$ & $\begin{array}{c}-0.0629 \\
(0.132)\end{array}$ \\
\hline Age & $\begin{array}{l}0.0015 \\
(0.002)\end{array}$ & $\begin{array}{c}-0.0001 \\
(0.002)\end{array}$ & $\begin{array}{l}0.0017 \\
(0.002)\end{array}$ & $\begin{array}{l}0.0064 \\
(0.011)\end{array}$ & $\begin{array}{l}0.0027 \\
(0.004)\end{array}$ & $\begin{array}{c}-0.0002 \\
(0.004)\end{array}$ & $\begin{array}{c}-0.0008 \\
(0.003)\end{array}$ & $\begin{array}{l}0.0001 \\
(0.003)\end{array}$ \\
\hline Pat & $\begin{array}{r}-0.1773^{\star} \\
(0.106)\end{array}$ & $\begin{array}{c}-0.0090 \\
(0.118)\end{array}$ & $\begin{array}{c}-0.1593^{*} \\
(0.094)\end{array}$ & $\begin{array}{c}-0.0510 \\
(0.128)\end{array}$ & $\begin{array}{c}-0.3323 \\
(0.361)\end{array}$ & $\begin{array}{c}-0.1841 \\
(0.208)\end{array}$ & $\begin{array}{l}0.1306 \\
(0.157) \\
\end{array}$ & $\begin{array}{c}-0.1748 \\
(0.148)\end{array}$ \\
\hline Roemployee & $\begin{array}{l}0.0212 \\
(0.023)\end{array}$ & $\begin{array}{c}0.2017^{\star * *} \\
(0.064)\end{array}$ & $\begin{array}{c}0.0895^{\star \star} \\
(0.041)\end{array}$ & $\begin{array}{l}0.0250 \\
(0.030)\end{array}$ & $\begin{array}{l}0.0130 \\
(0.030)\end{array}$ & $\begin{array}{c}-0.2607 \\
(0.223)\end{array}$ & $\begin{array}{l}0.0392 \\
(0.051)\end{array}$ & $\begin{array}{c}0.2223^{* *} \\
(0.097)\end{array}$ \\
\hline Owner & $\begin{array}{c}0.2921^{* *} \\
(0.124)\end{array}$ & $\begin{array}{c}0.0977 \\
(0.099)\end{array}$ & $\begin{array}{l}0.1632^{*} \\
(0.085)\end{array}$ & $\begin{array}{c}0.3147^{* *} \\
(0.125)\end{array}$ & $\begin{array}{l}0.2410 \\
(0.214)\end{array}$ & $\begin{array}{c}0.5755^{\star * *} \\
(0.210)\end{array}$ & $\begin{array}{l}0.0256 \\
(0.135) \\
\end{array}$ & $\begin{array}{l}0.2516 \\
(0.167)\end{array}$ \\
\hline Turnvar & $\begin{array}{l}0.0003 \\
(0.001)\end{array}$ & $\begin{array}{c}-0.0012 \\
(0.001)\end{array}$ & $\begin{array}{c}-0.0008 \\
(0.001)\end{array}$ & $\begin{array}{c}-0.0000 \\
(0.001)\end{array}$ & $\begin{array}{l}0.0006 \\
(0.004)\end{array}$ & $\begin{array}{l}0.0009 \\
(0.001)\end{array}$ & $\begin{array}{l}0.0019 \\
(0.001)\end{array}$ & $\begin{array}{c}-0.0000 \\
(0.001)\end{array}$ \\
\hline Widerange & $\begin{array}{c}-0.0387 \\
(0.081)\end{array}$ & $\begin{array}{l}0.0898 \\
(0.101)\end{array}$ & $\begin{array}{l}0.0501 \\
(0.077)\end{array}$ & $\begin{array}{c}-0.1001 \\
(0.109)\end{array}$ & $\begin{array}{l}0.0326 \\
(0.204)\end{array}$ & $\begin{array}{c}-0.0202 \\
(0.176)\end{array}$ & $\begin{array}{c}-0.1637 \\
(0.113)\end{array}$ & $\begin{array}{c}0.3104^{* *} \\
(0.151)\end{array}$ \\
\hline Replace & $\begin{array}{l}0.1353^{\star} \\
(0.080)\end{array}$ & $\begin{array}{c}0.2565^{\star * *} \\
(0.099)\end{array}$ & $\begin{array}{l}0.1311^{\star} \\
(0.078)\end{array}$ & $\begin{array}{c}0.3176^{* * *} \\
(0.104)\end{array}$ & $\begin{array}{l}0.2029 \\
(0.208)\end{array}$ & $\begin{array}{c}0.035 \\
(0.166)\end{array}$ & $\begin{array}{l}0.1796 \\
(0.114)\end{array}$ & $\begin{array}{l}0.2388^{\star} \\
(0.138)\end{array}$ \\
\hline Market & $\begin{array}{l}0.1258 \\
(0.085)\end{array}$ & $\begin{array}{c}-0.0860 \\
(0.105)\end{array}$ & $\begin{array}{l}0.0670 \\
(0.079)\end{array}$ & $\begin{array}{l}0.0525 \\
(0.120)\end{array}$ & $\begin{array}{l}-0.175 \\
(0.208)\end{array}$ & $\begin{array}{c}0.0031 \\
(0.199)\end{array}$ & $\begin{array}{l}0.0949 \\
(0.120)\end{array}$ & $\begin{array}{c}0.789 \\
(0.153)\end{array}$ \\
\hline Pquality & $\begin{array}{l}0.0595 \\
(0.082) \\
\end{array}$ & $\begin{array}{c}0.2118^{\star *} \\
(0.102)\end{array}$ & $\begin{array}{l}0.1149 \\
(0.078)\end{array}$ & $\begin{array}{l}0.1342 \\
(0.112) \\
\end{array}$ & $\begin{array}{c}-0.0731 \\
(0.202)\end{array}$ & $\begin{array}{l}0.1147 \\
(0.184)\end{array}$ & $\begin{array}{l}0.0208 \\
(0.118)\end{array}$ & $\begin{array}{l}0.1439 \\
(0.146)\end{array}$ \\
\hline Processes & $\begin{array}{l}0.1413^{*} \\
(0.081)\end{array}$ & $\begin{array}{c}0.2147^{\star *} \\
(0.105)\end{array}$ & $\begin{array}{c}0.2280^{\star * *} \\
(0.078)\end{array}$ & $\begin{array}{l}0.0215 \\
(0.111)\end{array}$ & $\begin{array}{c}-0.2421 \\
(0.192)\end{array}$ & $\begin{array}{l}0.2346 \\
(0.198)\end{array}$ & $\begin{array}{c}0.3008^{\star *} \\
(0.118)\end{array}$ & $\begin{array}{l}0.2146 \\
(0.145)\end{array}$ \\
\hline Regulation & $\begin{array}{c}1.5144^{\star * *} \\
(0.075)\end{array}$ & $\begin{array}{c}1.5202^{\star * *} \\
(0.096)\end{array}$ & $\begin{array}{c}1.5670^{\star * *} \\
(0.071)\end{array}$ & $\begin{array}{c}1.4315^{\star * *} \\
(0.107)\end{array}$ & $\begin{array}{c}1.7540^{* * *} \\
(0.198)\end{array}$ & $\begin{array}{c}1.7060^{* * *} \\
(0.155)\end{array}$ & $\begin{array}{c}1.8148^{* * *} \\
(0.110)\end{array}$ & $\begin{array}{c}1.5008^{\star * *} \\
(0.139)\end{array}$ \\
\hline Savings & $\begin{array}{c}0.3937^{\star * *} \\
(0.083)\end{array}$ & $\begin{array}{c}0.5820^{* * *} \\
(0.102)\end{array}$ & $\begin{array}{c}0.4108^{\star * *} \\
(0.080)\end{array}$ & $\begin{array}{c}0.5809^{* * *} \\
(0.108)\end{array}$ & $\begin{array}{c}0.9452^{* * *} \\
(0.193)\end{array}$ & $\begin{array}{c}0.6787^{\star * *} \\
(0.201)\end{array}$ & $\begin{array}{c}0.4061^{\star * *} \\
(0.119)\end{array}$ & $\begin{array}{l}0.2469^{\star} \\
(0.147)\end{array}$ \\
\hline Size & $\begin{array}{c}-0.0019 \\
(0.002)\end{array}$ & $\begin{array}{c}0.0002^{\star * *} \\
(0.000)\end{array}$ & $\begin{array}{c}0.0003^{\star * *} \\
(0.000)\end{array}$ & $\begin{array}{l}0.0000 \\
(0.000)\end{array}$ & $\begin{array}{c}0.0006^{\star *} \\
(0.000)\end{array}$ & $\begin{array}{l}0.0001 \\
(0.000)\end{array}$ & $\begin{array}{l}0.0001 \\
(0.000)\end{array}$ & $\begin{array}{l}0.0001 \\
(0.000)\end{array}$ \\
\hline \multicolumn{9}{|c|}{ Cooperation } \\
\hline 2 & $\begin{array}{l}0.0680 \\
(0.117) \\
\end{array}$ & $\begin{array}{l}0.1894 \\
(0.142)\end{array}$ & $\begin{array}{l}0.0081 \\
(0.112)\end{array}$ & $\begin{array}{c}0.3938^{\star * *} \\
(0.141)\end{array}$ & $\begin{array}{c}0.6047^{\star *} \\
(0.251)\end{array}$ & $\begin{array}{l}0.4867^{\star} \\
(0.264)\end{array}$ & $\begin{array}{l}0.2233 \\
(0.157)\end{array}$ & $\begin{array}{l}0.0060 \\
(0.203)\end{array}$ \\
\hline 3 & $\begin{array}{l}0.0032 \\
(0.096)\end{array}$ & $\begin{array}{l}0.0867 \\
(0.116)\end{array}$ & $\begin{array}{l}0.0135 \\
(0.088)\end{array}$ & $\begin{array}{l}0.1929 \\
(0.139)\end{array}$ & $\begin{array}{c}0.136 \\
(0.216)\end{array}$ & $\begin{array}{l}0.3025 \\
(0.204)\end{array}$ & $\begin{array}{l}0.1112 \\
(0.142)\end{array}$ & $\begin{array}{c}-0.0570 \\
(0.172)\end{array}$ \\
\hline
\end{tabular}


End of Table A4

\begin{tabular}{|c|c|c|c|c|c|c|c|c|}
\hline & \multicolumn{2}{|c|}{ Size } & \multicolumn{2}{|c|}{ Age } & \multicolumn{2}{|c|}{ Process/product } & \multicolumn{2}{|c|}{ NTF/NTM } \\
\hline & $\begin{array}{l}\text { small } \\
<100\end{array}$ & $\begin{array}{c}\text { big } \\
\geq 100\end{array}$ & $\begin{array}{c}\text { old } \\
<1990\end{array}$ & $\begin{array}{c}\text { new } \\
\geq 1990\end{array}$ & process & product & NTF & NTM \\
\hline Nofun & $\begin{array}{l}0.0680 \\
(0.080)\end{array}$ & $\begin{array}{l}0.1850^{*} \\
(0.103)\end{array}$ & $\begin{array}{l}0.0574 \\
(0.079)\end{array}$ & $\begin{array}{c}0.1868^{\star} \\
(0.107)\end{array}$ & $\begin{array}{c}-0.2048 \\
(0.193)\end{array}$ & $\begin{array}{l}0.2065 \\
(0.178)\end{array}$ & $\begin{array}{l}0.252^{\star *} \\
(0.120)\end{array}$ & $\begin{array}{l}0.0867 \\
(0.146)\end{array}$ \\
\hline Highivcost & $\begin{array}{c}-0.1129 \\
(0.083)\end{array}$ & $\begin{array}{l}0.0043 \\
(0.113)\end{array}$ & $\begin{array}{c}-0.1027 \\
(0.084)\end{array}$ & $\begin{array}{l}0.0244 \\
(0.113)\end{array}$ & $\begin{array}{c}0.195 \\
(0.215)\end{array}$ & $\begin{array}{l}0.1222 \\
(0.196)\end{array}$ & $\begin{array}{c}-0.0675 \\
(0.124)\end{array}$ & $\begin{array}{l}0.0885 \\
(0.152)\end{array}$ \\
\hline Nostaff & $\begin{array}{c}-0.2807^{\star *} \\
(0.124)\end{array}$ & $\begin{array}{c}-0.0533 \\
(0.192)\end{array}$ & $\begin{array}{c}-0.2129 \\
(0.138)\end{array}$ & $\begin{array}{c}-0.2081 \\
(0.165)\end{array}$ & $\begin{array}{c}-0.0071 \\
(0.330)\end{array}$ & $\begin{array}{c}-0.3823 \\
(0.259)\end{array}$ & $\begin{array}{c}-0.3387^{\star} \\
(0.198)\end{array}$ & $\begin{array}{l}-0.446 \\
(0.285)\end{array}$ \\
\hline Notecinfo & $\begin{array}{l}0.2103 \\
(0.145)\end{array}$ & $\begin{array}{l}0.1564 \\
(0.211)\end{array}$ & $\begin{array}{l}0.2238 \\
(0.156)\end{array}$ & $\begin{array}{l}0.2450 \\
(0.195)\end{array}$ & $\begin{array}{l}0.3048 \\
(0.406)\end{array}$ & $\begin{array}{c}0.7825^{\star * *} \\
(0.289)\end{array}$ & $\begin{array}{c}0.4961^{\star *} \\
(0.215)\end{array}$ & $\begin{array}{l}0.2375 \\
(0.328)\end{array}$ \\
\hline Nomarketinfo & $\begin{array}{c}-0.1083 \\
(0.127)\end{array}$ & $\begin{array}{c}-0.1523 \\
(0.221)\end{array}$ & $\begin{array}{c}-0.2577^{\star} \\
(0.142)\end{array}$ & $\begin{array}{l}0.0016 \\
(0.173)\end{array}$ & $\begin{array}{c}-0.2138 \\
(0.322)\end{array}$ & $\begin{array}{c}-0.1250 \\
(0.281)\end{array}$ & $\begin{array}{c}-0.2783 \\
(0.197)\end{array}$ & $\begin{array}{c}-0.3365 \\
(0.258)\end{array}$ \\
\hline Nopartner & $\begin{array}{c}-0.2521^{\star *} \\
(0.123)\end{array}$ & $\begin{array}{c}-0.0048 \\
(0.177)\end{array}$ & $\begin{array}{c}-0.1790 \\
(0.124)\end{array}$ & $\begin{array}{c}-0.2598 \\
(0.172)\end{array}$ & $\begin{array}{c}-0.9024^{\star *} \\
(0.357)\end{array}$ & $\begin{array}{l}0.0011 \\
(0.265)\end{array}$ & $\begin{array}{c}-0.1349 \\
(0.179)\end{array}$ & $\begin{array}{c}-0.1203 \\
(0.247)\end{array}$ \\
\hline Estfirms & $\begin{array}{l}0.1692^{*} \\
(0.092)\end{array}$ & $\begin{array}{c}-0.0275 \\
(0.126)\end{array}$ & $\begin{array}{l}0.0976 \\
(0.092)\end{array}$ & $\begin{array}{l}0.1182 \\
(0.126)\end{array}$ & $\begin{array}{c}0.4831^{\star *} \\
(0.222)\end{array}$ & $\begin{array}{c}-0.1293 \\
(0.198)\end{array}$ & $\begin{array}{c}-0.1217 \\
(0.132)\end{array}$ & $\begin{array}{l}0.2416 \\
(0.176)\end{array}$ \\
\hline Uncertd & $\begin{array}{l}-0.190 \\
(0.084)\end{array}$ & $\begin{array}{c}-0.1451 \\
(0.114)\end{array}$ & $\begin{array}{c}-0.0170 \\
(0.083)\end{array}$ & $\begin{array}{c}-0.0600 \\
(0.119)\end{array}$ & $\begin{array}{c}-0.3767^{\star} \\
(0.218)\end{array}$ & $\begin{array}{l}0.0635 \\
(0.189)\end{array}$ & $\begin{array}{c}-0.0068 \\
(0.119)\end{array}$ & $\begin{array}{l}0.0483 \\
(0.160)\end{array}$ \\
\hline Pastiv & $\begin{array}{l}0.1145 \\
(0.253)\end{array}$ & $\begin{array}{c}-0.3298 \\
(0.371)\end{array}$ & $\begin{array}{c}-0.2172 \\
(0.293)\end{array}$ & $\begin{array}{l}0.2810 \\
(0.328)\end{array}$ & $\begin{array}{c}-0.1516 \\
(0.499)\end{array}$ & Omitted & $\begin{array}{c}-0.0663 \\
(0.381)\end{array}$ & $\begin{array}{l}0.5300 \\
(0.373)\end{array}$ \\
\hline Nodemand & $\begin{array}{l}0.0752 \\
(0.241)\end{array}$ & $\begin{array}{c}-0.5178 \\
(0.434) \\
\end{array}$ & $\begin{array}{l}0.1782 \\
(0.272)\end{array}$ & $\begin{array}{c}-0.7781^{*} \\
(0.447)\end{array}$ & $\begin{array}{l}0.5486 \\
(0.340)\end{array}$ & $\begin{array}{c}-0.1034 \\
(0.513)\end{array}$ & $\begin{array}{c}-0.3666 \\
(0.366) \\
\end{array}$ & omitted \\
\hline Interinfo & $\begin{array}{c}0.1652^{\star *} \\
(0.079)\end{array}$ & $\begin{array}{l}0.0070 \\
(0.103)\end{array}$ & $\begin{array}{c}0.1944^{* *} \\
(0.076)\end{array}$ & $\begin{array}{c}-0.1209 \\
(0.109)\end{array}$ & $\begin{array}{l}0.3179^{*} \\
(0.192)\end{array}$ & $\begin{array}{l}0.1712 \\
(0.166)\end{array}$ & $\begin{array}{c}-0.0167 \\
(0.113)\end{array}$ & $\begin{array}{c}-0.0939 \\
(0.143)\end{array}$ \\
\hline Instinfo & $\begin{array}{c}0.2554^{* * *} \\
(0.091)\end{array}$ & $\begin{array}{l}0.0993 \\
(0.108)\end{array}$ & $\begin{array}{c}0.2309^{* * *} \\
(0.085)\end{array}$ & $\begin{array}{l}0.1193 \\
(0.121)\end{array}$ & $\begin{array}{c}-0.2033 \\
(0.234)\end{array}$ & $\begin{array}{l}0.3424^{*} \\
(0.199)\end{array}$ & $\begin{array}{l}0.1097 \\
(0.128)\end{array}$ & $\begin{array}{l}0.2380 \\
(0.154)\end{array}$ \\
\hline Marketinfo & $\begin{array}{l}0.0483 \\
(0.071) \\
\end{array}$ & $\begin{array}{c}-0.0578 \\
(0.089) \\
\end{array}$ & $\begin{array}{l}0.0029 \\
(0.069) \\
\end{array}$ & $\begin{array}{l}0.0133 \\
(0.095) \\
\end{array}$ & $\begin{array}{l}0.0848 \\
(0.178) \\
\end{array}$ & $\begin{array}{c}-0.0122 \\
(0.154) \\
\end{array}$ & $\begin{array}{c}-0.0551 \\
(0.101) \\
\end{array}$ & $\begin{array}{l}0.0592 \\
(0.129) \\
\end{array}$ \\
\hline Otherinfo & $\begin{array}{l}0.0387 \\
(0.092)\end{array}$ & $\begin{array}{l}0.0583 \\
(0.121)\end{array}$ & $\begin{array}{l}0.0510 \\
(0.090) \\
\end{array}$ & $\begin{array}{l}0.0823 \\
(0.126)\end{array}$ & $\begin{array}{c}0.766^{\star * *} \\
(0.253)\end{array}$ & $\begin{array}{c}-0.1464 \\
(0.212)\end{array}$ & $\begin{array}{c}0.01524 \\
(0.127)\end{array}$ & $\begin{array}{c}-0.1995 \\
(0.171) \\
\end{array}$ \\
\hline Cons & $\begin{array}{c}-2.2373^{\star * *} \\
(0.2173)\end{array}$ & $\begin{array}{c}-2.0578^{\star * *} \\
(0.266)\end{array}$ & $\begin{array}{c}-2.3465^{\star * *} \\
(0.207)\end{array}$ & $\begin{array}{c}-2.2516^{* * *} \\
(0.297)\end{array}$ & $\begin{array}{c}-3.0395^{\star * \star} \\
(0.508)\end{array}$ & $\begin{array}{c}-3.3794^{\star * *} \\
(0.567)\end{array}$ & $\begin{array}{c}-1.6707^{\star * *} \\
(0.2692)\end{array}$ & $\begin{array}{c}-2.5605^{\star * \star} \\
(0.376)\end{array}$ \\
\hline Wald & $\begin{array}{c}\chi^{2}(34)= \\
670.93 \\
(0.000)\end{array}$ & $\begin{array}{c}\chi^{2}(34)= \\
483.75 \\
(0.000)\end{array}$ & $\begin{array}{c}\chi^{2}(34)= \\
803.66 \\
(0.000)\end{array}$ & $\begin{array}{c}\chi^{2}(34)= \\
386.43 \\
(0.000)\end{array}$ & $\begin{array}{c}\chi^{2}(33)= \\
167.31 \\
(0.000)\end{array}$ & $\begin{array}{c}\chi^{2}(33)= \\
209.29 \\
(0.000)\end{array}$ & $\begin{array}{c}\chi^{2}(34)= \\
433.80 \\
(0.000)\end{array}$ & $\begin{array}{c}\chi^{2}(33)= \\
206.02 \\
(0.000)\end{array}$ \\
\hline $\begin{array}{l}\text { Wald test } \\
\text { exogeneity }\end{array}$ & $\begin{array}{c}\chi^{2}(2)= \\
5.14 \\
(0.077)\end{array}$ & $\begin{array}{c}\chi^{2}(2)= \\
3.61 \\
(0.164)\end{array}$ & $\begin{array}{c}\chi^{2}(2)= \\
4.15(0.126)\end{array}$ & $\begin{array}{c}\chi^{2}(2)= \\
2.67(0.263)\end{array}$ & $\begin{array}{c}\chi^{2}(2)= \\
3.61 \\
(0.165)\end{array}$ & $\begin{array}{c}\chi^{2}(2)= \\
1.04 \\
(0.593)\end{array}$ & $\begin{array}{c}\chi^{2}(2)= \\
0.77 \\
(0.682)\end{array}$ & $\begin{array}{c}\chi^{2}(2)= \\
6.80 \\
(0.033)\end{array}$ \\
\hline Obs & 2097 & 1244 & 2236 & 1105 & 422 & 537 & 1133 & 608 \\
\hline
\end{tabular}

Note: $\left({ }^{*}\right)$ significant at the $10 \%$ level of significance; $\left({ }^{* *}\right)$ significant at the $5 \%$ level of significance; $\left({ }^{* *}\right)$ significant at the $1 \%$ level of significance. 
Pablo DEL RÍO is Senior (tenured) Researcher and head of the Environmental Economics Group at the Institute for Public Policies and Goods at the National Research Council of Spain (CSIC). He holds a $\mathrm{PhD}$ in Environmental Economics (Universidad Autónoma de Madrid) and a MSc in Economics and Business (Universidad Autónoma de Madrid). He has been involved in $8 \mathrm{EU}$-funded projects as a partner and has more than 80 international publications in world-class journals. Research interests: drivers to eco-innovation, analysis of support schemes for the promotion of renewable energy technologies and interactions between renewable energy support schemes and CO2 mitigation instruments.

Desiderio ROMERO-JORDÁN is Associate Professor of Applied Economics at the Universidad Rey Juan Carlos. He has a PhD in Economics from Universidad Complutense de Madrid and has many publication in international, peer-reviewed journals. Research interests: economic analysis of taxes, energy demand, innovation and transport demand.

Cristina PEÑASCO is a Post-doc Researcher at the Institute for Public Policies and Goods, National Research Council of Spain (CSIC). She has a PhD in Economics from University Rey Juan Carlos. She is an expert in the use of statistical and econometric techniques and their application to the analysis of environmental, energy and innovation policies. Her research has led to several publications in world-class journals in the energy economics and eco-innovation areas. She has also been involved as a researcher in EU-funded projects. 